\title{
La Efectividad de la Tutela Jurisdiccional y la Ejecución de las Decisiones Judiciales
}

César Ernesto Luperdi Gamboa

Profesor de Derecho Civil y Procesal Civil de la Universidad Católica Santo Toribio de Mogrovejo (Chiclayo) y de Especialización en Derecho Empresarial de la Universidad Privada del Norte (Trujillo).

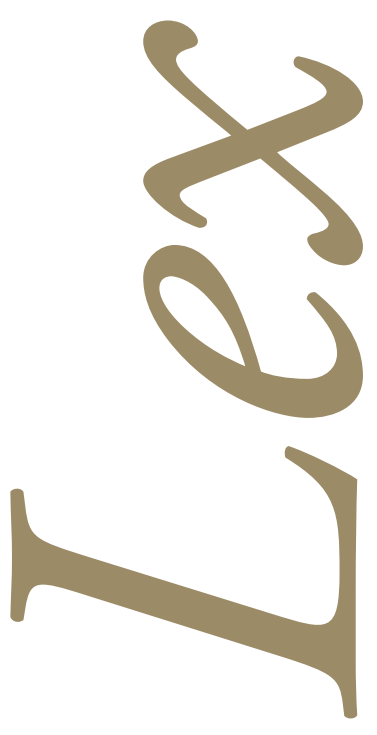




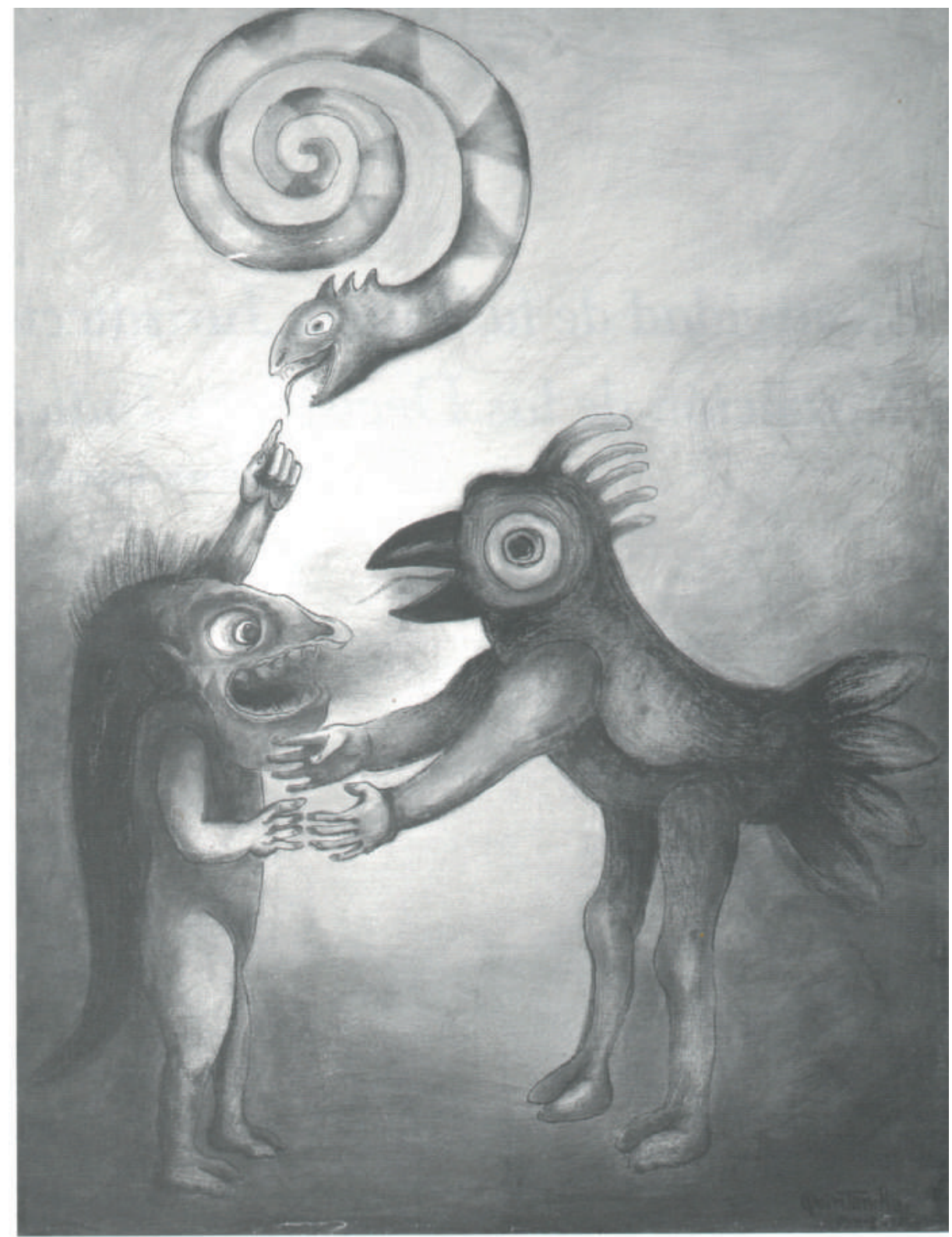

Óleo, 1994 (146 cm x 14 cm). 


\section{UMARIO}

I. Importancia del tema. II. Tutela Jurisdiccional efectiva y la actuación de lo decidido. III. La ejecución de las resoluciones judiciales. IV. Ideas básicas sobre cómo hacer cumplir las resoluciones judiciales. V. Algunos mecanismos legales para hacer cumplir lo ordenado judicialmente. VI. Cuándo es imposible, o casi imposible, ejecutar el mandato judicial. VII. Reformulando el proceso de ejecución. VIII. A modo de conclusión. IX. Bibliografia consultada.

\section{IMPORTANCIA DEL TEMA}

No es un secreto la actual crisis del sistema judicial peruano, asi debo señalar que parte importante del descrédito de aquel está basado en la poca confianza de los justiciables, porque muchas veces obtienen la decisión final (sentencia) cuando el interés real de la parte procesal ha desaparecido. Uno de los problemas constantes que afronta el proceso es el tiempo que demora resolver un caso concreto, ya sea por la carga procesal o por la dilatación innecesaria del obligado que pretende hacer más lato el iter procésal para precisamente no cumplir con su prestación; es más, la frustración del derecho del interesado no solo podrả ser causada por la demora en obtener una sentencia firme, sino también porque puede ser consecuencia del tiempo adicional que se requerirá para actuar (o ejecutar) lo decidido en el proceso, que en ocasiones puede durar igual o más que el propio proceso declarativo en si.

Considero que para las partes procesales, este es uno de los mayores problemas en la obtención de tutela jurisdiccional, pues la efectividad de lo resuelto está sujeta a una etapa o proceso (de ejecución) tedioso que, si bien cuenta con reglas para actuar lo resuelto, muchas veces se tarda demasiado. 
Bajo ese contexto, resulta adecuado revisar la forma cómo procede la actuación (o ejecución) de las decisiones judiciales para verificar si cumple de modo adecuado su finalidad: hacer efectivo el derecho de quien ganó en el proceso o de quien tiene un titulo de ejecución especial a su favor, pues así se recobrará parte de la confianza de quienes recurren al Poder Judicial a pedir tutela.

\section{LA TUTELA JURISDICCIONAL EFECTIVA Y LA ACTUACIÓN DE LO DECIDIDO}

La trascendencia del derecho a la tutela jurisdiccional efectiva se inicia porque es considerado, por la legislación internacional, por la doctrina y por la jurisprudencia, como un derecho fundamental de la persona humana, que es congénito al sujeto de derecho.

En el ordenamiento nacional, la tutela jurisdiccional tiene naturaleza constitucional, en tanto que ha sido recogida como uno de los principios y derechos de la función jurisdiccional, según lo establecido en el inciso 3 del articulo $139^{\circ}$ de la Constitución vigente. Ahora bien, desde el plano legal, la tutela jurisdiccional (vista como el lado dinámico de la jurisdicción) es aquel derecho del que goza toda persona para recurrir ante el órgano jurisdiccional y pedir tutela para sus derechos sustantivos, sea como demandante o como demandado, con la garantia que obtendrá una decisión ajustada a un debido proceso. Esta es la idea que muestra el Código Procesal Civil en el articulo I de su Titulo Preliminar.

Tradicionalmente, y atención a lo regulado en el artículo antes mencionado del Código Adjetivo, se ha entendido que el derecho a la tutela jurisdiccional efectiva se ha materializado en el derecho de acción y de contradicción; sin embargo, cabe precisar que este derecho constitucional no se agota o acaba ahi, va mucho más allá. La tutela jurisdiccional abarca el derecho a pedir la intervención del juez competente en protección de un derecho concreto, a tener la posibilidad de ejercer una defensa adecuada dentro de todo el proceso, a obtener una sentencia arreglada a derecho que resuelva la litis o dirima la incertidumbre juridica, y finalmente, que dicha decisión final sea eficaz, es decir, que sea actuada (o ejecutada). Solo si se llega a este último plano se tendrá una tutela realmente efectiva, sino simplemente la decisión judicial será letra muerta, un papel impreso que no generará cambio o alteración en la realidad'.

1 En este punto, resulta importante compartir el pensamiento del profesor Jorge Peyrano, quien afirma que "en principio, cuando se presta un servicio de justicia en tiempo y forma adecuadas a la situación que se trata. Será, entonces, sinónimo de proceso adecuado a las circunstancias del caso. Pero, además, deberả ser un proceso útil, en el sentido de que no reflejará únicamente en una hoja de papel a modo de declaración académica sin resonancias prácticas en la vida y patrimonio de los justiciables. (...). La sumatoria de lo adecuado y de lo útil configura un proceso eficiente". (Peyrano, Jorge. "La Acción Preventiva". En: Congreso Internacional de Derecho Procesal Civil, Lima: Fondo de Desarrollo Editorial de la Universidad de Lima, 2003, pp. 24-25). 
Entonces, queda evidenciado que la tutela jurisdiccional efectiva se manifestará en los siguientes niveles:

a) El acceso a la jurisdicción: esta es la manifestación clásica de la tutela jurisdiccional, pues implicará que toda persona con capacidad procesal, por su sola calidad, tiene el derecho de recurrir ante el fuero judicial a pedir tutela para su derecho, iniciando asi la actividad jurisdiccional. El derecho de acción es su clara expresión. La materialización de este derecho se verifica a diario cuando el justiciable presenta una demanda solicitando se resuelva un conflicto de intereses o se elimine una incertidumbre, ambas con relevancia juridica; de igual modo, también se accederá a la jurisdicción cuando, por ejemplo, se solicite una medida cautelar fuera de proceso; siendo así, debe considerarse que para estar en esta fase solo se requerirá que el justiciable pida (formalmente) al órgano jurisdiccional tutela para sus derechos, cualquiera sea el tipo de tutela y el sustento invocado.

b) El debido proceso: como ya lo hemos señalado, la tutela jurisdiccional efectiva debe obtenerse dentro de un proceso debido, según el Código Procesal Civil. En este punto encontramos distintas posiciones sobre la relación de la tutela jurisdiccional y el debido proceso, veamos brevemente: (i) se afirma que el debido proceso constituye una manifestación de la tutela jurisdiccional; (ii) de otro lado, se señala que respecto de estos conceptos solo opera un orden secuencial, primero opera la tutela jurisdiccional y en segundo orden el debido proceso; (iii) otra posición considera que los dos institutos son sustancialmente lo mismo; y (iv) finalmente, se explica que la tutela jurisdiccional y el debido proceso son manifestaciones de tradiciones juridicas diferentes, la primera proviene de la tradición juridica romano-germánica, y el segundo se deriva de la tradición jurídica del common law. ${ }^{2}$

Más allá de adoptar por una u otra posición, lo importante es reconocer que ambos conceptos son complementarios, porque si no existe un proceso debido no podemos decir que la tutela jurisdiccional otorgada fue realmente efectiva, y viceversa. Entendiendo que el debido proceso es aquel derecho que le corresponde a todo justiciable a exigir al Estado un proceso con las garantias mínimas que se orienten a obtener una decisión imparcial y arreglada a derecho, que no necesariamente deberá versar sobre el fondo del asunto; es más, de tal concepción se desprende que si este derecho (al debido proceso) no se concreta no se otorgará una tutela jurisdiccional adecuada, qué duda cabe.

El Tribunal Constitucional, en diversas resoluciones, ha establecido que el debido proceso está integrado por los siguientes elementos: la presunción de inocencia, el derecho de defensa; los principios de culpabilidad, legalidad y tipicidad cuando se imponen sanciones; el derecho al

2 Hurtado Reyes, Martin. Tutela Jurisdiccional Diferenciada, 1 ra. Edición; Lima: Palestra Editores, 2006, p. 45. 
juez natural; el derecho a la pluralidad de instancias, a los medios de prueba; la garantía de no autoincriminación; la posibilidad de aplicar y ejecutar sentencias; el principio non bis in idem; entre otros ${ }^{3}$. Cabe precisar que esta relación no es restrictiva sino extensiva (o abierta).

c) La eficacia de la decisión judicial: este último nivel en donde se expresa la tutela jurisdiccional efectiva implica la materialización de lo resuelto en la decisión judicial, normalmente en sentencia; asi, por regla general, a este nivel se llegará cuando exista una decisión final estimatoria. Cabe precisar que la eficacia de las decisiones judiciales no es exclusividad de las sentencias de mérito, en todo caso, ella es su más clara expresión; pues cabe recordar que toda resolución judicial válida genera efectos jurídicos para quienes intervienen en el proceso, por ejemplo, igual actuación (o ejecución) requerirá un mandato cautelar que imponga una obligación de hacer o de no hacer.

En este extremo, cabe hacer una precisión importante. En ocasiones, la eficacia de las sentencias puede agotarse con la misma declaración judicial, en tanto que no requiere de actos materiales posteriores a la expedición de la resolución judicial para que tal pronunciamiento sea eficaz, o cause cambios en el mundo real. Asi tenemos, por ejemplo, si se declara fundada una demanda de divorcio o de nulidad, esta no requerirá de acto material de ejecución posterior, la simple expedición de la sentencia significará de modo automático un cambio: el vinculo matrimonial existente quedó disuelto; es más, se puede afirmar que la expedición de la misma sentencia (declarativa o constitutiva) significa una satisfacción procesal plena y automática cuando adquiere firmeza ${ }^{4}$. En otros casos, la eficacia de la sentencia estará condicionada a la ejecución de actos posteriores, que precisamente serán los que efectivizarán el mandato judicial (sean sentencias o autos) y alterarán o mantendrán la realidad de acuerdo a lo resuelto u ordenado por el juez; por ejemplo, si en sentencia se ordena la restitución de un bien mueble, su emisión no importará una eficacia real, en tanto requerirá adicionalmente de unh acto de ejecución: la entrega efectiva de la posesión del bien (traditio). En este último supuesto hablamos, en estricto, de la llamada ejecución de las resoluciones judiciales.

De otro lado, la eficacia de la decisión judicial implica naturalmente su cumplimiento pleno, es decir, que el obligado a "ejecutar algo" lo haga de acuerdo a lo ordenado por el juez, en los propios términos de la resolución judicial, sin admitir variación, alteración o interpretación, por regla general. La ejecución de las decisiones judiciales puede darse de dos formas: por el cumplimiento voluntario del obligado o por la ejecución forzada. El primer supuesto se da

3 Esta relación corresponde al estudio realizado por Marcial Rubio, quien ha consolidado los principales pronunciamientos del Tribunal Constitucional peruano de cuatro años, de 2001 a 2005. (RUbto CORREA, Marcial. La Interpretación de la Constitución según el Tribunal Constitucional, Lima: Fondo Editorial PUCP, 2005, pp. 317. 328).

4 Monroy Palacios, Juan José. La Tutela Procesal de los Derechos, Lima: Palestra Editores, 2004, pp. 242-243. 
cuando quien resulta obligado a ejecutar el mandato expedido por el juez cumple por si mismo, se entiende por propia voluntad, asi el vencido ejecuta la orden judicial sin mayor oposición; en cambio, en el segundo supuesto, es el juez quien ejerciendo su poder de ejecución (executio) hace cumplir en forma compulsiva o coercitiva lo ordenado judicialmente, se entiende frente a la negativa u oposición del obligado.

\section{La ejecución de las decisiones judiciales como elemento esencial de la tutela jurisdic- cional $^{5}$}

El derecho a la tutela jurisdiccional se hará efectiva cuando precisamente lo resuelto a través de un proceso debido sea ejecutado; por tanto, resulta que la ejecución de la decisión judicial es parte fundamental para otorgar una tutela efectiva, pues como afirma el profesor Montero Aroca: "la jurisdicción no se limita a declarar el derecho. La función jurisdiccional comprende también la ejecución del mismo"; y haciendo referencia al articulo 117.3 de la Constitución Española precisa que "en la fórmula constitucional ello se expresa con las palabras "juzgando y haciendo ejecutar lo juzgado". ${ }^{6}$

Ahora bien, el derecho a ejecutar las decisiones judiciales no solo ha sido expresado en Tratados Internacionales, sino que además ha sido reconocido por nuestra Constitución (aunque de un modo implícito) al establecerse en el inciso 2 de su articulo $139^{\circ}$ que "ninguna autoridad puede (...) dejar sin efecto resoluciones que han pasado en autoridad de cosa juzgada, (...), ni modificar sentencias ni retardar su ejecución”. Entonces, tal es la importancia de este elemento esencial de la tutela jurisdiccional que se le ha otorgado rango constitucional por norma propia.

En tal sentido, el propio Tribunal Constitucional ha reconocido que la ejecución de las decisiones judiciales es un derecho que integra al de tutela jurisdiccional ${ }^{7}$. Finalmente, resul-

3 En este extremo, cabe hacer una precisión importante: hasta ahora hemos hecho referencia a la "actuación" de las resoluciones judiciales, en sentido genérico, aludiendo a cualquier acto que tenga por fin cumplir la decisión dictada por el órgano jurisdiccional, lo que implica a las decisiones (o sentencias) declarativas, constitutivas y de condena (estas últimas implican una orden de dar, hacer, o no hacer); sin embargo, de aqui en adelante, nos referiremos a la "ejecución" de resoluciones judiciales, en sentido estricto, a aquellos actos que realice el juez para que materialmente se hagan efectivas las decisiones de condena, segùn expondremos a lo largo de este trabajo.

- Montero Aroca, Juan y otros. El Nuevo Proceso Civil, Valencia: Tirant Lo Blanch, 2000, p. 575.

7 Este órgano, donde el supremo intérpreto la Constitución, en su sentencia del 06 de diciembre de 2002 , expedida en el proceso seguido por el Sindicato Unitario de Trabajadores Municipales del Rimac contra la Municipalidad Distrital del Rímac, sobre Acción de Amparo, Exp. No 1042-2002-AA/TC, ha expresado que "el derecho a la ejecución de las sentencias se encuentra contenido implicitamente en el derecho a la tutela jurisdiccional, reconocido en el inciso 3) del articulo $139^{\circ}$ de nuestra Constitución. En efecto, bien la referida norma no hace referencia expresa a la "efectividad" de las resoluciones judiciales, dicha cualidad se desprende de 
ta importante señalar que por la trascendencia de lo aquí discutido, en el ordenamiento legal peruano, se ha establecido el contenido del derecho a la tutela jurisdiccional efectiva (o, de la tutela procesal efectiva ${ }^{8}$ ), contemplándose de modo expreso como parte esencial de aquel al derecho de actuar (o ejecutar) lo decidido judicialmente; asi se aprecia del artículo $4^{\circ}$ del Código Procesal Constitucional, que prescribe: "se entiende por tutela procesal efectiva aquella situación juridica de una persona en la que se respetan, de modo enunciativo, sus derechos de libre acceso al órgano jurisdiccional, a probar, de defensa, al contradictorio e igualdad sustancial en el proceso, a no ser desviado de la jurisdicción predeterminada ni sometido a procedimiento distintos de los previstos por la ley, a la obtención de una resolución fundada en derecho, a acceder a los medios impugnatorios regulados, a la imposibilidad de revivir procesos fenecidos, a la actuación adecuada y temporalmente oportuna de las resoluciones judiciales y a la observancia del principio de legalidad procesal penal". De este modo, la eficacia de las decisiones judiciales (y especialmente de las sentencias) juega un rol protagónico dentro de la tutela jurisdiccional, máxime, si precisamente la tutela de los derechos de los justiciables es el fin del proceso, como lo señala Montero Aroca?.

\section{LA EJECUCIÓN DE LAS RESOLUCIONES JUDICIALES}

\subsection{La sentencias o resoluciones judiciales ejecutables}

Las sentencias estimatorias son los titulos de ejecución por excelencia; sin embargo, no

su interpretación, de conformidad con los tratados internacionales sobre derechos humanos (Cuarta Disposición Final y Transitoria de la Constitución). (...). De este modo, el derecho a la tutela jurisdiccional no solo implica el derecho de acceso a la justicia y el derecho al debido proceso, sino también el derecho a la "efectividad" de las resoluciones judiciales; busca garantizar que lo decidido por la autoridad jurisdiccional tenga un alcance práctico y se cumpla, de manera que no se convierta en una simple declaración de intenciones"; y sigue afirmando que "la actuación de la autoridad jurisdiccional en la etapa de ejecución de sentencias constituye un elemento fundamental e imprescindible en el logro de una "efectiva" tutela jurisdiccional, siendo de especial relevancia para el interés público, pues difícilmente se podria señalar la existencia de un Estado de derecho, cuando en su interior las personas no pueden lograr la justicia a través de los órganos establecidos para tal efecto. Para ello, la autoridad jurisdiccional deberá realizar todas aquellas acciones que tiendan a que los justiciables sean repuestos en sus derechos y compensados, si hubiera lugar a ello, por el daño sufrido. Conviene insistir en este componente del derecho a la tutela judicial efectiva, con objeto de que los propios órganos judiciales reaccionen frente a posteriores actuaciones o comportamientos que debiliten el contenido material de sus decisiones, pues sólo así se podrá satisfacer los derechos de quienes han vencido en juicio, sin obligarles a asumir la carga de nuevos procesos". (Ver texto completo en: http://tc,gob.pe/jurisprudencia/2003/01042-2002-AA.html)

5 Es adecuado indicar que el concepto de "tutela procesal efectiva" es teóricamente más amplio que el de "tutela jurisdiccional efectiva", pues el primero no sólo alude al contexto jurisdiccional o judicial, en donde se debe respetar este derecho fundamental, sino que también abarca los procedimientos administrativos y privados.

9 Entrevista al doctor Juan Montero Aroca. En: Suplemento de Análisis Legal "Juridica" del Diario Oficial El Peruano, 8 de noviembre de 2005 , Año 02, $\mathrm{N}^{\circ} 71, \mathrm{pp} .3-5$. 
son las únicas resoluciones judiciales que pueden ser ejecutadas, sino pensemos en una orden judicial provisional (como la medida cautelar) que disponga la suspensión de la construcción de una obra, esta también será una resolución judicial susceptible de ejecución. Asimismo, no toda decisión final (léase, sentencia fundada) es susceptible de ser ejecutada, pues no todas contendrán una orden de dar, hacer o no hacer.

Para entender mejor que decisiones son ejecutables, preliminarmente debemos saber qué es ejecutar una decisión judicial. En términos simples, ejecutar significa realizar o impedir conductas o actos materiales posteriores a la sentencia que conlleven a transformar, alterar, cambiar o mantener la realidad (o el mundo exterior, como algunos autores lo señalan), ajustándola precisamente a lo ordenado en el mandato judicial.

Bajo ese orden de ideas, considero adecuado recordar los tipos de sentencias que existen según el contenido de la pretensión propuesta, veamos: (i) la sentencia declarativa es aquella que tiene por objeto declarar la existencia o no de un derecho o una relación juridica; así, su simple expedición otorga tutela y satisface el interés del justiciable; (ii) la sentencia constitutiva existe cuando la decisión judicial, por si misma, crea, modifica o extingue un estado juridico, por ejemplo, haciendo cesar el que existe, modificándolo o sustituyéndolo, igual que la anterior su expedición satisface al demandante; y (iii) la sentencia de condena considera a la decisión final que impone al demandado el cumplimiento de una prestación, sea desde un punto de vista positivo (dar o hacer) o negativo (no hacer), e implica una orden judicial de condena: que entregue "algo", que haga "algo", que deshaga "algo", o que se abstenga de hacer "algo".

Entonces, bajo esta clasificación, una resolución o sentencia declarativa y constitutiva no pueden ser (en estricto) ejecutables, pues por si solas resultan ser suficientes para otorgar tutela efectiva y satisfacción procesal a la parte vencedora en el proceso; dicho de otro modo, su expedición se agotará en sí misma en tanto que no requiere de otro acto posterior a ella para efectivizar la pretensión estimada. Si bien es cierto en estos casos, normalmente, se realizan actos para, por ejemplo, inscribir una sentencia de nulidad o de divorcio, esta actividad no es en estricto una "ejecución"; por ello, parte de la doctrina se refiere que aquellas diligencias complementarias a la sentencia (que no agregan más efectos a la decisión judicial) como "ejecución impropia". Siendo asi, resulta que solo las resoluciones o sentencias de condena (las que contienen una obligación de dar, hacer o no hacer) puede generar la llamada "ejecución propia", pues a partir de este título de ejecución se iniciará una actividad que importe un cambio en el mundo real;

10 Montero afirma que esta terminologia resulta perturbadora, pues genera confusión respecto al significado real de la ejecución (MONTERo Aroca, Juan. Op. Cit. p. 576). Por ello, reiteramos, es preferible hablar de la "actuación" de las resoluciones judiciales (sean autos o sentencias), pues no todas importan una ejecución, reservándose el término "ejecución" de decisiones judiciales a las que importen una orden de dar, hacer o no hacer, y que se identifican con las llamadas "sentencias de condena" según la clasificación anotada. 
recordemos que para estos casos la tutela solicitada no se logrará con la simple declaración del derecho, como si sucede con las sentencias declarativas y constitutivas, sino que será necesario realizar actos materiales posteriores a la sentencia. ${ }^{11}$

\subsection{El título de ejecución}

En virtud del aforismo juridico nulla excutio sine titulo (no hay ejecución sin título) se requiere que la ejecución se inicie en virtud de un titulo, llamado también de ejecución. Este impondrá los limites a la pretensión del acreedor y a la actividad jurisdiccional.

Como ya se ha sostenido, por regla general, se considera como titulo de ejecución a aquellas sentencias que imponen al obligado el cumplimiento de determinada prestación: que entregue algo a alguien, que realice o se abstenga de efectuar ciertos actos o conductas, o que deshaga lo que ya realizó, por ejemplo. Pero, paralelamente a ellas, el ordenamiento juridico procesal también le reconoce ejecución a otros titulos especiales, tanto de naturaleza judicial como extrajudicial, entre ellos: la conciliación extrajudicial homologada (art. 328 y art. 688 inc. 3 del C.P.C), la transacción judicial y extrajudicial (art. $337 \mathrm{y}$ art. 688 inc. 8 del C.P.C), los laudos arbitrales firmes (art. 688 inc. 2 del C.P.C), los titulos valores (art. 688 inc. 4 del C.P.C), las garantias reales (art. 720 del C.P.C), entre otros más.

Dentro del esquema clásico de un proceso judicial, primero se declara el derecho y luego se procede con la ejecución; empero, exçepcionalmente, existen supuestos en donde la ejecución puede ser directa, esto es, sin que medie una declaración judicial previa. Estos casos se dan cuando la propia norma le reconoce mérito de ejecución a los titulos extrajudiciales.

\subsection{La forma de ejecutar}

El cumplimiento de lo ordenado en una sentencia puede realizarse de dos formas: (i) de forma voluntaria, y ocurre cuando el obligado a ejecutar la decisión judicial realiza la prestación impuesta por si mismo, sin que medie algún tipo de presión adicional, bastando solo la orden del juez; dicho de otro modo, será el ejecutado quien cumpla directamente lo ordenado judicialmente, sin que se oponga al mandato; o (ii) de modo coercitivo, cuando no existe libre voluntad del obligado a cumplir lo ordenado, se inicia un procedimiento o proceso en donde resulta indispensable que el juez realice actos posteriores para hacer efectiva la decisión judicial

11 En ese sentido, Couture señaló que "como las sentencias declarativas y constitutivas no imponen ei dar, hacer $u$ omitir algo, viene a resultar asi que la ejecución forzada, o simplemente ejecución, es el procedimiento dirigido a asegurar la eficacia práctica de las sentencias de condena". (Couture, Eduardo J. Fundamentos del Derecho Procesal Civil, Buenos Aires: Edit. De Palma, 1988, pp. 438-439). 
(sea auto o sentencia), como expresión de su jurisdicción: la coertio; precisamente, a esta forma de actuar la decisión o sentencia estimatoria se le denomina ejecución forzada, o simplemente ejecución. De esto se desprende el carácter sustitutivo de la actividad de ejecución, pues solo procederá en caso exista negativa directa o indirecta del obligado.

El Código Procesal Civil peruano ha previsto que la ejecución se puede realizar dentro del mismo proceso, y en un proceso autónomo; finalmente, esto dependerá del interés de la parte acreedora, pues recuérdese que el procedimiento o el proceso de ejecución se rige por el principio de dispositivo: solo se inicia, se continúa y se concluye a pedido del acreedor. Siendo asi, corresponderá al interesado solicitar al juzgado inicie el procedimiento de ejecución forzada de la sentencia como la última etapa del proceso cognoscitivo; o en todo caso, pedir el cumplimiento de la resolución judicial final en un nuevo proceso, el de ejecución, según lo previsto en los articulos $715^{\circ} \mathrm{y}$ siguientes del Código Procesal Civil.

En cualquier supuesto, si una decisión judicial impone a un sujeto determinado la obligación de cumplir con lo que debe: dando, haciendo, deshaciendo u omitiendo algo, la actividad jurisdiccional deberá dirigirse a obtener el cumplimiento total de lo decidido con el fin de obtener una satisfacción plena del interés del ejecutante, ya que toda persona y autoridad está obligada a acatar y dar cumplimiento a las decisiones judiciales, en sus propios términos, sin poder calificar su contenido o sus fundamentos, restringir sus efectos o interpretar sus alcances, conforme a lo previsto en el articulo $4^{\circ}$ de la Ley Orgánica del Poder Judicial, por regla general. Consecuentemente, si algún extremo de la resolución no se ha ejecutado por actos externos al proceso o a la función jurisdiccional, la ejecución forzada deberá continuar cuando se restablezca en la realidad la posibilidad de seguir ejecutándola.

\section{IDEAS BÁSICAS SOBRE CÓMO HACER CUMPLIR LAS RESOLUCIONES JU. DICIALES}

En general, toda resolución judicial de condena podrá ser susceptible de ejecución forzada, siempre que el obligado no cumpla voluntariamente con la prestación a su cargo; pero para saber cómo podrá ejecutarse el mandato se debe tener en cuenta el tipo de obligación que fue incumplida, el interés en juego y la conducta del obligado.

\subsection{Ejecución de una obligación de dar}

La ejecución de una resolución que impone una obligación de dar se realizará de acuerdo al bien objeto de la prestación: una suma de dinero, un bien determinado o genérico, uno cierto

o incierto, con o sin valor patrimonial. Recién a partir de este conocimiento previo sabremos como debe proceder la ejecución. 
Si una sentencia ordena el pago de una determinada suma de dinero, el mandato de ejecución contendrá (además de la orden de pago) el apercibimiento de iniciarse la ejecución forzada sobre el patrimonio del deudor. Esto significa que frente a la negativa del obligado a cancelar una suma de dinero ordenada por el juez, este se sustituirá en su posición y realizará actos materiales por él: afectando los bienes necesarios para garantizar la acreencia, luego de ello, los rematará, y procederá a pagar la deuda con el resultado del remate de aquellos bienes afectados, o adjudicándolos en pago a favor del acreedor.

Obviamente esto es lo ideal; empero, ello no siempre sucede. Existen casos en los que el ejecutado no tiene bienes que respondan por la deuda, o teniéndolos no la cubren por ser insuficientes o por estar ya afectados por otros créditos, entre otros supuestos. Esto importará una imposibilidad material de ejecutar la sentencia; y en donde el acreedor deberá dejar la tutela específica, y optar por pedir la disolución y liquidación del deudor, según el procedimiento previsto en el artículo 692-A del Código Procesal Civil.

Cuando un mandato judicial contiene una obligación de dar un bien mueble cierto, específico o determinado, el juez intimará al ejecutado para que entregue el bien plenamente identificado; es decir, en este tipo de ejecución la actividad jurisdiccional estará direccionada a lograr que se otorgue la entrega y la posesión de la cosa debida a favor del ejecutante. Así, el mandato de ejecución requerirá la entrega del bien en litis, otorgando un plazo prudencial de acuerdo a la naturaleza de la prestación (que debe concordarse con el plazo previsto en el artículo $690^{\circ}$ del Código Procesal Civil), bajo apercibimiento de procederse a su entrega forzada, la que se realizará (de ser necesario) con auxilio de la fuerza pública, con descerraje y registro o cateo, conforme al artículo $705^{\circ}$ del Código Procesal Civil; y si el bien mueble no es entregado, sea porque el bien se destruyó, se deterioro, se sustrajo o se ocultó por el obligado, este será requerido a pagar el valor del bien mueble, siempre que haya sido demandado. Aquí tres notas personales que considero adecuado tener en cuenta: (i) el pago del precio, que compensará no tener el bien, deberá ser necesariamente a solicitud del acreedor, pues más allá que la ejecución sea netamente dispositiva, no se le puede "obligar" a recibir un bien (dinero) a cambio de otro (mueble); entonces, entendamos que esta compensación dineraria no es automática; (ii) no encuentro impedimento para que el juez, siempre a pedido de parte, pueda dictar otros apremios para lograr la entrega el bien mueble, pues recuérdese que al justiciable se le debe dar exactamente lo mismo a lo que tiene derecho, salvo que el mismo opte por otra prestación distinta; y (iii) si bien debemos seguir siendo respetuosos del principio de congruencia, y el juez por regla no puede ordenar algo distinto a lo pedido en la demanda, considero que se le debe reconocer al acreedor su derecho de pedir la compensación dineraria directamente en ejecución, como una excepción, previo traslado a la otra parte, en tanto que será justamente en esta etapa cuando se pueda verificar la necesidad y la forma como procederá la ejecución forzada. 
Ahora, si la resolución contiene una obligación de dar un bien inmueble, el mandato de ejecución ordenará la entrega este, $y$ por proporcionalidad, apercibirá que frente al incumplimiento se procederá al lanzamiento, incluso, con orden de descerraje y mediante el uso de la fuerza pública; procediéndose conforme a lo previsto en el articulo $593^{\circ}$ del Código Procesal Civil. Aqui creo que el tema puede resultar más fácil; empero, también podriamos repetir lo anotado y lo aplicable para la ejecución de entregar bienes muebles; reitero, siempre se debe buscar (en principio) la ejecución in natura de la prestación asumida o requerida.

Distinto es el caso cuando nos referimos a la entrega de bienes genéricos. Aquí se debe señalar que aquellos son bienes fungibles, es decir, sustituibles; por tanto, resulta que si el juzgador ordenó la entrega de un bien genérico, este puede ser sustituido por otro idéntico (entiéndase, en igual cantidad, y calidad), pero que no es el mismo; es más, resulta posible que el ejecutante vea satisfecho su interés con la sustitución en dinero, en tanto que con él (dinero) podrá adquirir el o los bienes de cualquier persona; pero recordemos, siempre que el acreedor lo pida.

\subsection{Ejecución de una obligación de hacer}

En este caso, la resolución judicial intimará al ejecutado para que realice "algo", concediendo un plazo de acuerdo a la naturaleza de la prestación (que debe concordarse con el plazo previsto en el artículo $690^{\circ}$ del Código Procesal Civil). El apercibimiento indicará que frente al incumplimiento, la prestación será ejecutada por un tercero, a cuenta y riesgo del deudor, este es el sentido del artículo $707^{\circ}$ del Código Procesal Civil.

Para que se pueda dictar el apercibimiento de acuerdo a la norma indicada, este debe ser parte del petitorio pretendido; siendo a la vez parte del pedido de ejecución; es decir, si el acreedor no solicita que la obligación la cumpla un tercero en caso el propio obligado no lo haga, el juzgador no podrá apercibirlo de este modo. Es más se impone al ejecutante la carga de señalar el valor aproximado que representa el cumplimiento de la obligación, y designar a la persona quien ejecutará la prestación en sustitución del deudor, sino léase el segundo párrafo del Art. $706^{\circ}$ del Código Procesal Civil. De modo particular, considero que inclusive en ejecución se debería permitir al acreedor ejecutante señalar al tercero encargado de la ejecución; siendo así, no deberia ser indispensable acumular en la demanda la pretensión de "ejecución por tercero", pues (reitero) la forma de cómo se realizará la ejecución forzada será establecida precisamente al final, ahi será cuando el ejecutante elija cómo se debe cumplir la prestación incumplida. Si no pensemos, bajo el esquema actual, si el acreedor no designa en su demanda al tercero, y si el deudor no quiere cumplir, el primero se verá impedido de obtener la ejecución de la prestación debida, pues ni el ejecutado lo hará ni se le permitirá que un tercero lo haga por el deudor; es más, qué pasaría si el tercero designado fallece (si es persona natural) o se liquida y se disuelve 
(si es persona juridica), estos hechos creo no deban impedir al ejecutante pueda designar a otro tercero para que ejecute (o haga) la prestación incumplida, siempre a cargo y cuenta del ejecutado; y previo traslado a la contraparte, para no afectar su derecho de defensa.

Una regla especial ha sido prevista cuando el "hacer" constituye una manifestación de la voluntad del ejecutado. Si la condena establecida judicialmente significa compeler al obligado a que exprese su voluntad para formalizar un documento, el apercibimiento consistirá en que frente a su negativa será el propio juez quien realice este "hacer", el que, por cierto, no deja de ser un tercero ajeno a la relación jurídico sustantiva. Por tanto, conforme a lo previsto en el articulo $709^{\circ}$ del C.P.C. el mandato de ejecución ordenará al ejecutado para que cumpla con formalizar el documento que otorgó (lo que implica una expresión de su voluntad), bajo apercibimiento de hacerlo en su nombre.

Ahora, si la resolución judicial impone una obligación para ejecutar una prestación de "hacer" que tenga la calidad de personalisima el tema resulta ser más complicado, pues solo el ejecutado y nadie más que él podrá realizar la conducta; por ejemplo, aquel famoso escritor que es contratado por una editorial para realizar una novela. Para estos casos, el apercibimiento previsto en el artículo $707^{\circ}$ del Código Adjetivo sería infructuoso, pues nunca se podrá materializar la pretensión por tercero; frente a ello el juzgador deberá imponer otro tipo de "apremios" aunque la norma no lo establezca expresamente. En efecto, esa falta de regulación explicita no debe implicar inacción del juzgador pues puede invocar el artículo $53^{\circ}$ del mismo Código para hacer cumplir el mandato (sea auto o sentencia) ${ }^{12}$. Asi tenemos, en estos casos, podrá apercibir al obligado para cumpla personalmente la prestación a su cargo bajo apercibimiento de imponerle multas progresivas, entre otros apremios, inclusive, no resultará inapropiado (en algunos casos: como aquel custodio judicial que, pese a las multas impuestas, no pone a disposición el bien afectado con medida cautelar) sostener que también procede la llamadà prisión civil. Quizás aqui se aprecie con mayor claridad la creatividad del juez, pues de ella dependerá que el apercibimiento sea un mecanismo eficaz para persuadir el obligạdo a ejecutar su prestación; en este sentido, no veo oportuno poner demasiados limites a la actividad del juez, pues lo que debe buscarse será otorgar tutela "efectiva", claro está, sin llegar arbitrariedades judiciales, pues para tales supuestos (arbitrarios) existen otros mecanismos que ya forman parte de nuestro sistema,

12 En este extremo, importante es indicar que el artículo $53^{\circ}$ del Código Procesal Civil señala las facultades coercitivas del juez, indicando que este puede: (i) imponer multas compulsivas y progresivas para hacer cumplir sus mandatos; y (ii) ordenar la detenciỏn por 24 horas, a quien se resista injustificadamente a cumplir su mandato. Ahora bien, más allá de que estas sean expresión de sus facultades disciplinarias (intra proceso), una interpretación adecuada que busque cumplir con los fines del proceso, nos lleva a aplicar estas facultades coercitivas tam. bièn en la fase de la ejecución de las decisiones judiciales; estas prerrogativas son, a mi criterio, indispensables para que el proceso llegue a su cause final y concreto: una ejecución real y efectiva de lo ordenado por el juez; pensar lo contrario, seria limitar la acrividad del juez y evitar que este pueda hacer efectiva sus decisiones. 
como la motivación de la decisión, la responsabilidad administrativa, civil y penal de los jueces, etcétera ${ }^{13}$.

De otro lado, frente a prestaciones personalísimas, tampoco se debe limitar el derecho del ejecutante de pedir la "compensación dineraria" por el incumplimiento de la prestación debida; esto deberia ser también algo que se le reconozca el acreedor ejecutante. Ello sin perjuicio de la indemnización por los daños y perjuicios que le corresponda, que tendria que haber sido acumulado o pretendido en otro proceso.

\subsection{Ejecución de una obligación de no hacer}

Una decisión judicial de condena contendrá una obligación de no hacer cuando se prohiba al ejecutado a realizar una conducta, esto puede referirse a actos determinados o a un plazo especifico $^{14}$; por ejemplo, que el deudor se abstenga de construir el sexto piso de su inmueble porque afecta una servidumbre de luz, o que no perturbe la posesión del ejecutante (arrendatario) hasta que termine el contrato de arrendamiento. Siendo asi, aquí la ejecución opera a la inversa; es decir, se tendrá por cumplido el mandato judicial no cuando se realicen actos materiales que alteren la realidad, sino cuando el ejecutado se abstenga de realizar determinados actos considerados en el titulo de ejecución, manteniendo el status quo, pues la ejecución de tales actos importará precisamente desobedecer lo ordenado judicialmente.

El mandato de ejecución ordenará al ejecutado se abstenga de continuar realizando algo (prestación personalisima, pues nadie más que él estará obligado a "no hacer algo"), o para que deshaga lo ya hecho, bajo apercibimiento de deshacerlo forzadamente, por tercero, bajo su costo y riesgo, así se ha establecido en el articulo $711^{\circ}$ del Código Procesal Civil. Cabe señalar que el juez puede elegir distintas opciones, según lo pida el ejecutante, por ejemplo, podrá ordenar que un tercero deshaga lo hecho (una edificación), o imponer multas cuando se trate de un hacer personalisimo, entre otros apremios. Inclusive, para estos supuestos, se hacen extensivos los comentarios dados sobre la ejecución de prestaciones de "hacer".

En resumen, los apercibimientos o apremios que se impondrán en el mandato de ejecución deberán ser los adecuados para conseguir la ejecución total y la satisfacción plena del interés del justiciable. El juzgado está facultado para adecuar el apercibimiento de acuerdo a la naturaleza

15 Lo que sucede es que tal sistema de responsabilidad de los jueces debe hacerse más efectivo para que en realidad los "malos jueces" sean ejemplarmente sancionados o condenados; por tanto, la ineficiencia de tal sistema no debe impedir u obstaculizar que el justiciable (con todo su derecho) vea que la sentencia que le da la razón sea plenamente ejecutada; de ahí que considero apropiado reconocerle (legalmente) más libertad al juez en la etapa de ejecución.

I4 Montero Aroca, Juan. Op.Cit. p. 731. 
de la obligación a ejecutarse y al caso concreto, sujeto al pedido del ejecutante, asi se desprende implicitamente de lo preceptuado en el artículo $715^{\circ}$ del Código Procesal Civil. Importa anotar que esta norma, en principio, no establece límites para imponer los apercibimientos, sin embargo. ello no debe significar conductas absurdas, arbitrarias o abusivas. ${ }^{15}$

\section{ALGUNOS MECANISMOS LEGALES PARA HACER CUMPLIR LO ORDENA. DO JUDICIALMENTE}

La ejecución de las decisiones judiciales es indispensable para otorgar tutela judicial a los justiciables, pues justamente aquella procurará que lo decidido se haga realidad en favor de quien venció en el proceso, o a favor de quien tiene un titulo de condena especial; entonces, no podrá hablarse de tutela efectiva si el mandato judicial (sentencia, o no) no se materializa en el mundo real. Es por ello, que el ordenamiento juridico no solo tiene que prever mecanismos para garantizar el acceso a la justicia, y la obtención de una decisión arreglada a derecho, sino que también debe regular aquellos medios para procurar que las decisiones judiciales se cumplan en sus propios términos, por regla general; de ahí que se vienen regulando diversos instrumentos para compeler al ejecutado a cumplir con lo que el juez ordena.

Bajo ese contexto, resulta importante revisar los principales mecanismos que se orientan a lograr el cumplimiento pleno de lo resuelto judicialmente.

\subsection{La llamada ejecución forzada: una precisión de su alcance}

La ejecución forzada surge a partir de que el ejecutado no cumple voluntariamente la resolución judicial, y es por su carácter sustitutorio que el juez será quien ejecute (forzadamente) lo decidido en el proceso. Entonces, deberá entenderse que ejecución forzada es toda actividad que realiza el órgano jurisdiccional para hacer cumplir coercitivamente el mandato judicial, en ejercicio de los poderes inherentes a su jurisdicción.

En este punto, haremos referencia a una resolución que utiliza arbitrariamente los apremios. Sucede que un juez, en aplicación del articulo $53^{\circ}$ del C.P.C., resuelve multar al demandado por no haber reintegrado una tasa judicial diminuta dentro del plazo concedido, para admitir su contestación de demanda; y en el mismo acto, requiere nuevamente el reintegro, bajo apercibimiento de doble pago de la multa impuesta (citada por ARIANO DeHo, Eugenia. "Una Astreinte Endoprocesal?. (Reflexiones sobre las multas coercitivas del art. 53 CPC)". En: Problemas del Proceso Civil, Lima: Juristas Editores, 2003, pp. 383-284). Como vemos, la decisión del juez resulta alarmante, pues los jueces no pueden imponer apremios para cumplir cualquiera de sus ordenes, sino solo procederán para ejecutar aquellas que establezcan una obligación (de condena). Este caso es más paradojico (por decir lo menos) porque el no cumplimiento de los requisitos de la contestación no puede implicar una multa coercitiva, sino, por ser una carga procesal, simplemente se tendria por no presentado el escrito, nada más. Entonces, no olvidemos el buen uso de estos medios coercitivos o compulsivos. 
Para nuestro caso, el Código Procesal Civil ha establecido que la forma de ejecución forzada son dos: el remate y la adjudicación (Articulo $725^{\circ}$ ). Sin embargo, esta regulación no es del todo correcta pues implicará una limitación a la ejecución como mecanismo para hacer efectiva la tutela jurisdiccional. Como podemos apreciar, el Código Adjetivo nacional solo ha regulado a la ejecución forzada en base a mandatos judiciales que contienen una obligación de dar suma de dinero; pero estas decisiones no son las únicas que pueden dictarse y ejecutarse forzadamente. Es decir, según esta regulación se podria asumir (indebidamente) que solo las sentencias de condena que ordenen el pago de una suma de dinero podrán ser objeto de la ejecución forza$\mathrm{da}^{16}$, posición que no comparto.

Esta omisión de las normas adjetivas: de no regular la ejecución de las obligaciones de dar (distintas a la dar suma de dinero), hacer o no hacer, no nos debe hacer asumir que no existe ejecución forzada en tales casos; sino pensemos: si frente al incumplimiento del ejecutado de entregar la posesión de un bien inmueble, el juzgador ordena el lanzamiento del ejecutado, con la autorización para el descerraje, y con el auxilio de la fuerza pública (policias), ¿acaso eso no es ejecutar forzadamente una decisión judicial? Por tanto, cuando nos refiramos al término "ejecución forzada" no deberá entenderse que solo se materializa a través del remate o adjudicación, como mal asume nuestro Código Procesal, sino que refiere a todo acto jurisdiccional que conlleve a ejecutar coercitivamente el mandato del juez, incorporando, inclusive, los apremios necesarios: multas, prisión civil, ejecución por tercero, entre otras formas.

\subsection{La subrogación por un tercero}

Cuando el titulo de ejecución (la sentencia o auto de condena) contenga la intimación para que el obligado entregue o haga algo, frente a su negativa de ejecutar directa y voluntariamente lo ordenado, el juez puede ordenar (a pedido de parte) que un tercero ejecute la prestación, realizando todo acto necesario para otorgar satisfacción plena al acreedor. Obviamente, esta forma de ejecutar las decisiones judiciales se hará siempre que no se trate de obligaciones personalísimas, pues en estos supuestos solo el propio obligado podrá ejecutar la prestación, atendiendo

16 En este sentido, y siendo la nomenclatura del Código Procesal Civil, el magistrado Héctor Lama afirma que "sólo derivará a la EJECUCIÓN FORZADA, aquellas SENTENCIAS DE CONDENA que contengan una orden de pago, sea de dar una suma líquida o iliquida, en este caso liquidable con operación aritmética. (...) No llegará a la EJECUCIÓN FORZADA, como es lógico aquellas SENTENCIAS DE CONDENA que disponen u ordenan la entrega o restitución, según el caso, de bienes ciertos, sean éstos muebles o inmuebles: (...), tampoco llegará a la ejecución forzada aquella sentencia de condena, que ordene al demandado al cumplimiento de una obligación de hacer". (LAma MORE, Héctor. "La Sentencia como Título de Ejecución. Critica a los Art. 713 y 715 del C.P.C.". En: La Revista Virtual Hechos de la Justicia, N 05, Enero-Marzo 2005. Ver pảg. web: http://www. hechosdelajusticia.org/quinta.htm). Por su lado, siguiendo la misma linea de pensamiento, Juan Monroy Pa. lacios indica que "la fase de ejecución forzada resultarả adecuada cuando estamos frente a situaciones juridicas que suponen una prestación dineraria”. (Monroy PALACios, Juan José. Op. Cit. p. 249). 
a sus cualidades personales, $\mathrm{y}$ tales supuestos deberán aplicarse otros apremios para procurar la actuación de tales resoluciones judiciales.

En ese sentido, los articulos $706^{\circ}, 707^{\circ}$ y $708^{\circ}$ del Código Procesal Civil ha regulado la subrogación de un tercero en la ejecución de una obligación de hacer. Estas normas han establecido que si el deudor no cumple con ejecutar la prestación a su cargo, será el juez quien nombre a un tercero (designado por el ejecutante) para que cumpla con hacer lo debido, se entiende en forma exacta a como está en el título de ejecución.

En lo relacionado a las obligaciones de dar, el Código Adjetivo no ha previsto que la ejecución pueda hacerse por un tercero. Sin embargo, ello no impide al juzgador para que (a solicitud del interesado) ordene también la ejecución por un tercero, pues no existe impedimento para que un sujeto distinto al obligado pueda entregar (a cuenta de este) un bien fungible o sustituible, la regla anterior podria aplicarse extensivamente. En lo que respecta al cumplimiento de una prestación de no hacer, esta resulta ser personalisima, y por tanto no cabe la subrogación indicada, salvo en el supuesto que implique deshacer lo hecho, que puede ser ejecutado por tercero, con cargo del ejecutado.

En cualquier supuesto, el costo de la ejecución realizada por el tercero estará a cargo del deudor; asi lo prevé el Código en relación a las obligaciones de hacer; de este modo, se generará un crédito a favor del tercero y a cargo del obligado que podrá ser exigido en el mismo proceso, conforme al articulo $708^{\circ}$ del Código Procesal Civil.

En este extremo, me parece adecuado hacer dos comentarios: (i) aunque parezca excesivo, considero que el precio o costo por la ejecución a cargo del tercero puede ser mayor al pactado con el deudor, pues lo que debe importar (por regla general) es la ejecución in natura de la prestación, y además el ejecutado debe asumir las cargas o consecuencias de su conducta omisiva; esto no debe implicar, por otro lado, una arbitrariedad. Por tanto, el costo si bien puede ser superior al establecido con el ejecutado, debe ser el regular ségún el mercado, para esto una solución práctica es realizar una tasación judicial, salvo que las partes se ponga de acuerdo. (ii) Ahora cabe preguntarnos ¿qué pasa con el tercero y el crédito que se generó justamente por ejecutar la prestación a cargo del ejecutado si éste también se rehúsa a pagar?, es más, ¿qué sucede si el deudor no tiene patrimonio con que pagar la actividad del tercero? En estos supuestos, no se puede perjudicar a una persona que no fue comprendida en el proceso (el tercero que ejecutó) para beneficiar a otra que obtuvo sentencia favorable (el ejecutante), parafraseando a Bullard diriamos "para vestir a este santo, tendriamos que desvestir a otro", lo que no es una salida muy razonable. Siendo así, en el primer supuesto, se tendria que asegurar el crédito del tercero con medidas cautelares, $y$ en el segundo simplemente estariamos frente a una sentencia inejecutable en ese sentido, pues el deudor que no quiere ejecutar, tampoco tiene patrimonio 
para pagar el costo del tercero que ejecutará su prestación; en ese escenario no debe descartarse la aplicación otros mecanismos de la ejecución forzada.

\subsection{Las multas coercitivas}

Este tipo de medio compulsivo busca persuadir al ejecutado para que ejecute directamente la prestación a su cargo. El apercibimiento de multa ejerce (o por lo menos pretende) una presión psicológica para obtener el cumplimiento "espontáneo" de lo ordenado, de modo inmediato y pleno. Es en ese sentido, que el artículo $53^{\circ}$ inciso 1 del Código Procesal Civil ha señalado como una de las facultades coercitivas del juez a la multa, utilizándola como mecanismo destinado "a que la parte o quien corresponda, cumpla sus mandatos con arreglo al contenido de su decisión". Recordemos que, en mi opinión, esta facultad coercitiva disciplinaria también puede (y debe) ser utilizada para buscar la ejecución de las decisiones judiciales.

Según el precepto legal mencionado, esta multa es compulsiva (porque busca presionar a la obligado a fin de que cumpla lo ordenado) y progresiva (pues no consiste en una sola suma fija sino que se va generando en ciertos plazos) ${ }^{17}$; asimismo, esta sanción compulsiva puede ser constante (se impone el mismo monto) o gradual (el monto se va incrementando); al final su imposición quedará sujeta a la discrecionalidad del juez según lo prevé la propia norma procesal18. Además, debe de tenerse en cuenta que las multas se impondrán hasta que el obligado cumpla fielmente con el mandato judicial, en esa linea lo ha establecido expresamente, por ejemplo, el articulo $75^{\circ}$ inciso 1 de la Ley Procesal del Trabajo. Ahora bien, no hay que perder de vista que una vez impuesta la multa, esta puede ser reajustada o dejada sin efecto, siempre que el juzgador considere que el motivo del incumplimiento ha tenido o tiene justificación. Esta regla establecida en el artículo $53^{\circ}$ del Código Adjetivo es una excepción, porque el propio código (en principio) prohibe la exoneración de las multas, de acuerdo al artículo $420^{\circ}$ del mismo cuerpo legal.

Si bien es cierto las multas son sanciones que se orientan al cumplimiento de los mandatos judiciales, su imposición no procede frente a la inejecución de cualquier prestación. Parte de la doctrina afirma que su aplicación está restringida a los supuestos en donde se deje de ejecutar un mandato que implica una conducta personalisima, esto es, que no pueda ser realizada sino por el mismo ejecutado; considero que ello no es correcto, la multa debe ser aplicada frente al incumplimiento de una prestación personalisima o no; salvo en frente a una prestación de dar suma de dinero. Asi tenemos aquel caso del custodio judicial que no quiera poner a disposición

7. Ariano Deho, Eugenia. Op. Cit. p. 386.

15 El Código Procesal Constitución, en su articulo $22^{\circ}$, también ha establecido que corresponde al juez establecer el monto de las multas de modo discrecional; pero, además, ha establecido que la capacidad económica del obligado es parámetro importante para determinar el monto de la multa. 
del Juzgado los bienes afectados con medida cautelar o aquel obligado que no quiere entregar un bien mueble vendido al ejecutante, inclusive ocultándolo.

Para concluir, hay que precisar que este medio compulsivo no debe ser confundido con los astreintes, básicamente porque lo siguiente: (a) las multas se imponen en razón del incumplimiento del mandato judicial, en cambio los astreintes se establecen en correlación al perjuicio que sufre el ejecutante; y (b) el beneficiario de las multas es el Estado, en este caso el Poder Judicial; cosa distinta sucede con los astreintes, porque quien los recibe es el acreedor, como compensación por el incumplimiento. Este instituto de origen francés, astreintes, no está regulado en el Código Procesal Civil; por ello, concuerdo con Adrián Simons y con José Tam cuando afirman que resulta adecuado incorporar de modo expreso en las normas procesales a la figura astreintes como medio compulsivo ${ }^{19}$. La razón que encuentro es que la inejecución de la decisión judicial más que afectar al proceso (como instrumento de tutela de derechos) agravia al justiciable, en tanto que este es quien verá frustrado la materialización de su derecho, entonces, qué mejor que regular un mecanismo para sopesar en algo el perjuicio causado al acreedor si precisamente el proceso debe dirigirse a otorgarle tutela jurisdiccional frente un caso justiciable; es más, no olvidemos que este es el fin que persigue el proceso.

\subsection{La detención provisional del obligado: la llamada prisión civil}

Por este mecanismo legal, el propio juez que emitió la resolución (no ejecutada) puede disponer en forma directa la detención del obligado, cuando este no cumpla lo ordenado por resolución judicial firme, o lo haga deficientemente. Este es otro medio compulsivo para hacer cumplir lo ordenado judicialmente, porque a través de él se presiona al obligado psicológicamente: ¿quién no se sentirá presionado si la resolución que le requiere cumplir una obligación lo apercibe bajo detènción efectiva, aunque sea por un dia?

En tal orientación, el articulo 53॰ inciso 2 del Código Procesal Civil ha previsto de modo expreso que el juez civil puede disponer la detención hasta por 24 horas de quien se resiste a cumplir su mandato sin justificación, ya sea produciendo agravio a la otra parte o a la majestad del servicio de justicia; para que la detención se haga efectiva se requiere un apercibimiento previo, sin él no puede procederse a una detención directa, sino seria ilegal e inconstitucional. Para mejor ilustración, recordamos el ejemplo antes propuesto: aquel custodio judicial que sea requerido para poner a disposición del juzgado el bien secuestrado, y no cumpla con su obligación a pesar de haberle impuesto multas, el juez puede apercibirlo con detención en caso su

19 Simons Pino, Adriản. "El derecho a la ejecución plena de la decisiones judiciales y los medios compulsorios procesales". En: Revista Peruana de Derecho Procesal, Tomo VI, Lima: Estudio Monroy Abogados, Mayo 2003, p. 461. Tam Perez, José. "Apuntes sobre la ejecución de sentencias en el proceso civil". En: Congreso Internacional de Derecho Procesal Civil, Lima: Fondo de Desarrollo Editorial de la Universidad de Lima, 2003, p. 143. 
conducta sea reiterada; si en una nueva oportunidad y frente a uno nuevo requerimiento sea renuente a entregar el bien, el juez puede disponer directamente su captura y detención por el plazo de ley; ello sin afectar la responsabilidad civil y penal que le corresponda al custodio.

Cabe anotar que este apremio se aplicará siempre que se trate de obligaciones personalisimas o no patrimoniales. Esto por lo siguiente: primero, frente a los demás supuestos (especialmente frente a incumplimiento de prestaciones dinerarias, donde está prohibida) procederán otros apercibimientos más efectivos para hacer cumplir la resolución judicial; y, segundo, la sanción de prisión (por su gravedad) es de última ratio. ${ }^{20}$

Finalmente, cabe anotar que esta sanción se aplicará y se hará efectiva sin perjuicio del cumplimiento de lo dispuesto en la resolución judicial.

\subsection{La penalización de la conducta}

Entendiendo que la ejecución de las decisiones judiciales forma parte de la tutela jurisdiccional, y que es precisamente aquella la que le otorga eficacia a los mandatos de condena, algunos ordenamientos jurídicos han tipificado el incumplimiento del mandato judicial como un delito, reprimible normalmente con pena privativa de la libertad. Este mecanismo compulsivo, como las multas y la prisión civil, busca intimar al obligado para que (forzando su voluntad) cumpla con la prestación a su cargo. Algo al parecer bastante efectivo, en teoria.

En nuestro ordenamiento, se ha previsto un supuesto genérico en donde se penaliza esta conducta. El artículo $368^{\circ}$ del Código Penal que regula el delito de desobediencia o resistencia a la autoridad ha prescrito: "el que desobedece o resiste la orden impartida por un funcionario público en el ejercicio de sus atribuciones, salvo que se trate de la propia detención, será reprimido con pena privativa de libertad no mayor de dos años". Dentro de este tipo penal, se ha incluido la conducta de aquellos que encontrándose obligados por decisión judicial incumplen (sin justificación válida) lo ordenado por el juez. Si bien es cierto se establece un supuesto bastante genérico, se debe precisar que solo se iniciará el proceso penal frente a la no ejecución de obligaciones establecidas por resoluciones judiciales firmes. Además, debemos tomar en cuenta que el anoticiamiento de un juez extrapenal al Ministerio Público, para que este ejercite la acción penal pública, debe aplicarse en forma restrictiva, y siempre que se haya decretado como apercibimiento, atendiendo al principio de minima intervención del Derecho Penal, acogido por el nuevo sistema acusatorio-adversarial.

20. Por su lado, Aldo Zelada, con un importante aporte, afirma que la prisión civil puede ordenarse según los siguientes criterios: (i) debe tenerse en cuenta los intereses en juego, y por ende, será útil se trata de tutelar derechos no patrimoniales; y (ii) solo puede ser usada cuando otro medio no sea igual de eficaz para lograr el cumplimiento de la resolución judicial. (Zela Villeg.As, Aldo. La Tutela Preventiva de los Derechos (como manifesta. ción de la tutela diferenciada), Lima: Palestra Editores, 2008, p. 217). 
De otro lado, habrá que hacer una precisión importante. Por disposición de la Constitución, el articulo $2^{\circ}$ inciso 24 acápite c, se ha determinado que "no hay prisión por deudas"; esto significa que no podrá aperturarse proceso penal frente al incumplimiento de una sentencia judicial firme que contenga una orden de pago, es decir, una obligación de dar suma de dinero. Sin embargo, esta misma norma admite una excepción: "este principio no limita el mandato judicial por incumplimiento de deberes alimentarios". Dentro de esta excepción encontramos a los delitos que a continuación describimos.

El articulo $149^{\circ}$ del Código Penal tipifica el delito de omisión a la asistencia alimentaria, señalando: "el que omite su obligación de prestar los alimentos que establece una resolución judicial será reprimido con pena privativa de libertad no mayor de tres años, o con prestación de servicio comunitario de veinte a cincuentidós jornadas, sin perjuicio de cumplir el mandato judicial. (...) Si el agente ha simulado otra obligación de alimentos en connivencia con otra persona, o renuncia o abandona maliciosamente su trabajo la pena será menor de uno ni mayor de cuatro años". Como podemos apreciar lo que se castiga penalmente es la conducta de incumplir un mandato judicial, que establece una pensión de alimentos; pero además, se precisa (con buen criterio) que también se comete delito cuando se pretende burlar o frustrar la ejecución del mandato judicial, simulando otra obligación alimentaria o dejando el trabajo con el objeto no pagar.

El otro delito que resulta estar dentro de la excepción es el denominado violación de la libertad de trabajo, regulado en el articulo $168^{\circ}$ del Código Penal. El tipo penal es el siguiente: "la misma pena [privativa de libertad no mayor de dos años] se aplicará al que incumple las resoluciones consentidas o ejecutoriadas dictadas por autoridad competente". Entendemos que por el carácter alimentario de los beneficios sociales también se sanciona penalmente a aquellos empleadores que son renuentes a cumplir con los mandatos judiciales que imponen la obligación de pago a favor de un determinado trabajador. Para la aplicación de este articulo se debe tener en cuenta lo señalado en el artículo $75^{\circ}$ de la Ley Procesal del Trabajo, en donde se señala que "si el demandado se resiste a cumplir las obligaciones de hacer o de no hacer, el Juez adoptará las siguientes medidas: (...) si persistiera en el incumplimiento, denunciar penalmente al demandado por el delito contra la libertad de trabajo o resistencia a la autoridad"; entonces, se advierte que en materia laboral el legislador ha previsto mecanismos más severos con el fin de garantizar la ejecución plena a la sentencia judicial firme.

\subsection{Las medidas cautelares y las medidas ejecutivas}

Estos son los instrumentos más adecuados para posibilitar la ejecución de las decisiones judiciales, cuando se trate de sentencias de fondo; es decir, de aquellas que resuelvan la controversia discutida en el proceso. Obviamente, en estas pocas lineas no agotaremos un tema tan 
importante y controversial, sin embargo, se quiere dejar algunas apreciaciones que sirvan de base para reconocer el valor que ambas figuras tienen en la búsqueda de la efectivización de los mandatos judiciales.

Las medidas cautelares, en términos simples, se entiende como aquel instrumento que sirve para gaiantizar de la mejor manera la actuación (o la ejecución) de la sentencia definitiva. De esta idea, se aprecia que la finalidad de la medida cautelar es precisamente asegurar la actuación de la sentencia estimativa; en otras palabras, buscará que se den las condiciones necesarias para que (en su debido momento) la decisión final y firme pueda ser efectivizada, sea voluntaria o forzadamente.

En ese mismo sentido, el artículo $608^{\circ}$ del Código Procesal Civil preceptúa que la medida cautelar está "destinada a asegurar el cumplimiento de la decisión definitiva". Por tanto, a través de esta medida provisional se trata de prever que la sentencia no sea imposible de actuar, justamente porque a través de ella se afectará el patrimonio del deudor (medidas para futura ejecución forzada: embargo y secuestro), se publicitará la litis para restar la buena fe de los terceros (anotación de demanda), se adelantará la ejecución de lo que decidirá en sentencia (medida temporal sobre el fondo), se repondrá o se conservará un estado de hecho y de derecho (medida innovativa y de no innovar), pretendiendo neutralizar los peligros que pudieran alterar, afectar, perturbar o impedir la actuación de la decisión final.

El Código Adjetivo ha previsto de modo expreso que medidas cautelares pueden ser solicitadas en un proceso judicial en busca de garantizar el cumplimiento pleno de la sentencia; empero, si alguna de las medidas típicas no resulta adecuada o suficiente para asegurar la actuación de la decisión definitiva, el juez puede conceder (a pedido de parte o via adecuación) una medida cautelar genérica, esto es, una no prevista en el Código (art. 629 del C.P.C.).

Entendiendo que la medida cautelar resulta ser un instrumento que genera efectos jurídicos en contra del ejecutado (o demandado), su concesión y ejecución están supeditados al cumpli. miento de los siguientes requisitos:

(i) Para la concesión de la medida cautelar: (a) la verosimilitud del derecho, o fumus boni iuris, se presenta (normalmente) cuando el solicitante acredita (prima facie) al juez que existen motivos razonables para que "aparentemente" su pretensión sea acogida en sentencia, persuadiéndolo que tiene un derecho por reconocer, lo que no debe significar por parte del magistrado un juzgamiento definitivo, sino provisional. (b) El peligro en la demora, o periculum in mora, implica que el transcurso del iter procesal pone en peligro la eficacia de la decisión final; por tanto, se justificará la decisión cautelar si existe la posibilidad que el ejecutado anule o disminuya la eficacia de la sentencia si esperamos concluir con el proceso, con todo lo que eso implique. Estos requisitos son exigidos por el artículo $611^{\circ}$ del Código Adjetivo. 
Adicionalmente, parte de la doctrina considera que el tercer presupuesto para otorgar una medida cautelar es la adecuación ${ }^{21}$, que se manifiesta en: (a) un aspecto cualitativo, que busca la conexidad entre la pretensión principal y el pedido cautelar solicitado; y (b) un aspecto cuantitativo, orientado a requerir la necesaria correlación entre el derecho con contenido patrimonial que se pretender asegurar y la medida cautelar. Asimismo, se afirma que debe entenderse (además) que existe este requisito cuando la medida es proporcional y necesaria, es decir, si es adecuada y razonable al logro del fin que se busca, y si es la que afecta en menor grado la esfera juridica del ejecutado (el llamado Principio de Mínima Injerencia). Si bien es cierto este requisito no se ha regulado expresamente en el Código Procesal Civil, como si sucede en la Ley del Proceso Contencioso Administrativo y en el Código Procesal Constitucional, no significa que no deba evaluarse en los procesos civiles, porque en términos simples la adecuación es una expresión del Principio de Congruencia Procesal que debe estar presente en toda decisión judicial, siendo así, se puede concluir que el pedido cautelar no puede ir más allá de la pretensión principal y de lo estrictamente necesario para cautelarla. ${ }^{22}$

(ii) Para la ejecución de la medida cautelar: la caución, o la llamada contracautela, que puede ser personal o real, es una garantía que otorga el solicitante a favor del afectado para poder ejecutar la medida cautelar ya concedida, y tiene como finalidad resarcir los daños que se puedan causar al ejecutado si la medida cautelar deviene en innecesaria. Cabe resaltar que su preexistencia a la ejecución asegura (en teoria) un rápido resarcimiento al ejecutado, en un incidente post-cautelar. Este requisito está regulado los articulos $613^{\circ}$ y $614^{\circ}$ del Código Procesal Civil.

Por el contrario, las medidas ejecutivas son aquellos instrumentos que no se orientan a garantizar la eficacia de la sentencia, sino que permiten al acreedor ejecutante (a partir de una sentencia estimatoria firme) iniciar los actos propiamente de ejecución, pues a través de aquellas se adaptarán las condiciones para el cumplimiento del mandato. En nuestro Código Procesal Civil, este tipo de medidas se rigen por las reglas de lass medidas cautelares, de ahi la confusión entre ambas. Siguiendo a Monroy Palacios ${ }^{23}$, las diferencias entre unas y otras se pue-

21 Monror Palacios, Juan José. Bases para la Formación de una Teoria Cautelar, Lima: Ed. Comunidad, 2002, pp. 186-199.

22 Cabe indicar que esto no implica que el juez esté impedido de otorgar una medida cautelar distinta a la solici. tada en el cuaderno respectivo; pues, conforme al articulo $611^{\circ}$ del Código Procesal Civil, el juez puede dictar la medida cautelar en la forma solicitada o "la que considere adecuada atendiendo a la naturaleza de la pretensión principal". Lo que debe asumirse como requisito es que, por Congruencia Procesal, debe existir una relación lógica entre la pretensión principal y cautelar.

25 Monkor Palacios, Juan José. "Conversión de la medida cautelar en la fase de actuación de la sentencia". En: La Retista Virtual Hechos de la Justicia, № 01, Noviembre-Diciembre 2003. Ver pág. web: http://www.hechosdelajusticia.org/primera.htm. 
den resumir desde dos perspectivas: desde su estructura, las cautelares requieren presupuestos (verosimilitud del derecho, peligro en la demora, adecuación y contracautela) que no se exigen para las medidas ejecutivas, porque en este último caso (a diferencia del primero, donde hay incertidumbre del derecho invocado) existe un estado de certeza producto de una sentencia fundada y firme; $y$ desde su función, las cautelares persiguen asegurar la eficacia de la decisión final, en cambio, las ejecutivas buscan dar inicio a los actos de ejecución para lograr una satisfacción procesal plena.

\subsection{La destitución del obligado}

Este medio compulsivo, está previsto en el artículo $22^{\circ}$ del Código Procesal Constitucional. En éste se señala que "la sentencia que ordena la realización de una prestación de dar, hacer o no hacer es de actuación inmediata. Para su cumplimiento [de la sentencia], y de acuerdo al contenido especifico del mandato y de la magnitud del agravio constitucional, el Juez podrá hacer uso de multas fijas o acumulativas e incluso indisponer la destitución del responsable". Dentro de un proceso constitucional, dada su naturaleza e importancia, éste resulta ser un mecanismo muy útil para lograr la efectividad de lo decidido; en tal sentido, los autores del mismo, consideran que este es uno de los instrumentos más agudos y contundentes para el fin deseado: la actuación plena del mandato judicial ${ }^{24}$. Entonces, bajo este contexto, si el juez en sentencia impone una obligación de dar, hacer o no hacer, este mismo puede disponer (previo apercibimiento) la destitución del obligado si este no ejecuta su decisión. Ahora, aunque parezca muy osado, debo señąlar que este apremio deberia también incorporarse a los procesos contenciosos administrativos, inclusive a los laborales o civiles, cuando corresponda, y siempre que el obligado actúe con dolo o culpa inexcusable.

Retomando el Código Procesal Constitucional, en su artículo $22^{\circ}$, hace una precisión en el siguiente sentido: "cualquier de estas medidas coercitivas [multas o destitución] debe ser incorporada como apercibimiento en la sentencia, sin perjuicio de que, de oficio o a pedido de parte, las mismas puedan ser modificadas durante la fase de ejecución". Sobre el particular, habría que señalar que una interpretación literal nos puede llevar a la siguiente conclusión: solo podrá destituir al obligado siempre que en la sentencia se haya incluido el apercibimiento; la pregunta es ¿qué pasa si no se incluyo el apercibimiento en la sentencia?, ¿acaso el juzgador estará imposibilitado de imponer (a pedido de parte) el apercibimiento de multa o de destitución al obligado? Personalmente, como ya se ha expuesto, considero que el juez puede establecer los apremios necesarios aunque no hayan sido incluidos en la decisión final. Teniendo en cuenta justamente la finalidad de la norma: buscar la actuación inmediata y plena de la sentencia,

24. Abad Yupanqut, Samuel y otros. Código Procesal Constitucional. Comentarios, Exposición de Motivos, Dictämenes e Indice Analitico. Lima: Palestra Editores, 2004, p. 48. 
resulta de un despropósito limitar el poder del juez para llegar a este objetivo, porque primero no se le puede desconocer al juzgador el poder inherente que tiene para compeler (o apercibir) al obligado buscando cumpla su mandato, $y$, segundo, si existe incumplimiento del ejecutado, es precisamente en ese momento en donde se le debe apercibir de acuerdo a su conducta. Además, se debe tomar en cuenta que la modificación del apercibimiento no se ve restringida por la norma procesal, y en todo caso el juez podrá imponer cualquiera, y luego sustituirla por la otra; pero siempre que tal decisión sea motivada, proporcional, y gradual.

\subsection{De la ejecución específica a la genérica: compensación dineraria}

Debemos entender que la ejecución es específica cuando al final de ella se llegue a dar al ejecutante exactamente la misma prestación contenida en el titulo de ejecución; es decir, la prestación realizada por el juzgador (ante la inactividad del ejecutado) ha de ser idéntica a aquella que realizaria el deudor si cumpliera voluntariamente la prestación declarada en el titulo. Por su parte, la ejecución será genérica cuando implique un cambio en la prestación establecida en el título, sustituyéndola por una equivalente, pero distinta; esta sustitución resulta ser siempre en dinero, ${ }^{25}$

En ese orden de ideas, nos encontramos frente a la llamada tutela sustitutoria cuando la ejecución especifica de lo resuelto judicialmente se sustituye por una prestación genérica y distinta: una compensación económica.

Nuestro ordenamiento juridico regula el cumplimiento especifico de las decisiones judiciales, en tanto que estas se cumplen en sus propios términos de acuerdo al articulo $4^{\circ}$ de la Ley Orgánica del Poder Judicial; por tanto, de acuerdo a esta norma el ejecutante está obligado a cumplir exactamente lo dispuesto por el juez, y no puede sustituir la prestación a su cargo. Lo cual como regla general estaria perfecto si se logra ejecutar la sentencia de acuerdo a lo ordenado; sin embargo, si no es así, deberian establecer este mecanismo (compensación económica) como excepción, siempre que así lo pide la parte ejecutante.

Independientemente de expuesto en el párrafo anterior, cabe reflexionar sobre la utilidad de la tutela sustitutoria. Por ejemplo, que sucede cuando (por la demora en la ejecución) se pierde el interés en la entrega de la cosa, o simplemente se torna físicamente imposible; asimismo, qué pasa si el mandato contiene obligaciones personalisimas, que no pueden ejecutarse por terceros, y el obligado no quiere ejecutar la prestación, no existiendo apremios (multas, prisión civil, o denuncia penal) que haga que cumpla lo ordenado; o en todo caso, en el supuesto que se establezca una obligación de no hacer, y al ejecutarse el mandato ya no se puede deshacer lo hecho; bajo esos casos, que son simplemente enunciativos, lo único que podrá otorgarse a

Montero Aroca, Juan. Op.Cit., p. 717. 
quien ganó en el proceso es una compensación (económica), optando sustitutoriamente por un equivalente pecuniario en lugar de la prestación originaria no ejecutada; sin perjuicio de los daños y perjuicios a que hubiere lugar a reclamar en proceso aparte. Ante este contexto, no ajeno a nuestra realidad, creo conveniente que se le reconozca al juez su prerrogativa para optar, en cualquier caso y siempre a pedido de parte, por la ejecución genérica, en busca de otorgar algún tipo de tutela al justiciable, aunque no sea en forma o modo en que lo pidió inicialmente en su demanda ${ }^{26}$. Ahora bien, en ejecución de sentencia nos encontrariamos con otros límites: la prohibición de modificar el petitorio de la demanda y el principio de congruencia; empero, creo que debe permitirse (excepcionalmente) en la etapa ejecución forzada esta conversión, en tanto que no se debe privar al ejecutante de buscar una tutela efectiva (aunque sea genérica), y en todo caso, el ejecutado debe asumir las consecuencias de su conducta renuente a cumplir el mandato de ejecución; ya bastante habrá esperado el ejecutante como para que se le permita al ejecutado siga burlándose del derecho acreedor y del propio órgano jurisdiccional.

Finalmente, debemos tener en cuenta que la gradualidad de los apremios o apercibimientos, debe estar en atención a la importancia y urgencia del mandado; pues a partir de estas circunstancias concretas el juez podrá imponerlos y adecuarlos, disponiendo su aplicación sucesiva, individual o conjunta; ello para no incurrir en los excesos y arbitrariedades. En tal sentido, el o los apremios que se dicten para cumplir el mandato judicial deben ser proporcionales y graduales, dependiente (en cada caso) del derecho en conflicto, del perjuicio que se causa al ejecutante, del interés y del pedido del acreedor, de la conducta del ejecutado, y del tipo mandado incumplido. Asimismo, resulta importante también indicar que la imposición de las sanciones por la inejecución del mandato judicial, no enerva la obligación de cumplirlo; es decir, los apremios se concretizarán sin perjuicio del cumplimiento de lo ordenado por el juez; es más, inclusive frente a aquellos actos homogéneos que se presenten en ejecución de sentencia dentro de los procesos de amparo, preceptuado en el artículo $60^{\circ}$ del Código Procesal Constitucional (en donde, en ejecución, se va allá de la pretensión del actor), o en su par regulado en el tercer párrafo del artículo 593 ${ }^{\circ}$ del Código Procesal Civil, refiriéndose al (re)lanzamiento por nuevo ingreso del poseedor ya lanzado, por ejemplo.

26 A la fecha, a partir de la modificación del Código Procesal Civil introducida por el D.Leg. No 1069 , se ha previsto en el articulo $705^{\circ} \mathrm{del}$ mismo Código que en el mandato ejecutivo se dispondrá que "en caso de no realizase la entrega [del bien mueble] por destrucción, deterioro, sustracción u ocultamiento atribuible al obligado, se le requerirá para el pago de su valor, si asi fue demandado". Entonces, hemos avanzado, pero creo que pudo hacerse al más; esto es, extendiendo esta conversión de la prerensión especifica a genérica para todos los casos, y siempre a pedido del ejecutante. 


\section{CUÁNDO ES IMPOSIBLE, O CASI IMPOSIBLE, EJECUTAR EL MANDATO JUDICIAL}

La tutela jurisdiccional para que sea realmente efectiva, como ya lo hemos visto, requiere de la materialización de lo decidido, es decir, de la ejecución de lo resuelto por el órgano jurisdicción; sin embargo, más de una vez, nos vamos a encontrar con casos en donde una resolución judicial resulta ser inejecutable, y no necesariamente por temas juridicos, sino de otra naturaleza, como sociales o politicos ${ }^{27}$. Por ejemplo, en virtud de la llamada "prenda genérica" se asume unánimemente que todos los bienes del patrimonio del deudor responden por las obligaciones asumidas por éste, con el limite cuantitativo de la deuda; empero, esto se ha limitado por temas juridicopolitico y por la realidad, pues existen bienes que no pueden afectarse por medida cautelar (los mal llamados "inembargables"), que no provocarán una ejecución forzada de la orden de pago; $\mathrm{y}$, en otros casos, tales bienes simplemente no existirán o habrán sido indebidamente transferidos para no pagar. Aqui existirá imposibilidad de ejecutar el mandato de pago, pues no podrá afectarse el patrimonio del deudor, $\mathrm{y}$ por ende, el acreedor no podrá efectivizar la resolución que le reconoce un derecho dinerario; dando una solución (que no parece la más feliz) el ordenamiento jurídico nos da la posibilidad de declara la disolución y liquidación del deudor (art. 692-A del C.P.C); salvo que el ejecutante quiera seguir esperando para ejecutar el mandato judicial, hasta que su deudor ejecutado tenga bienes, si es que los llega a tener, con lo que la espera se haria casi infinita, máxime, si estamos frente a un deudor de mala fe, que si compra lo hará a través de testaferros; claro está para estos efectos no hay que olvidar el plazo prescriptorio (de 10 años) que nos indica el articulo $2001^{\circ}$ inciso 1 del Código Civil. Obviamente, bajo estos supuestos no podrá iniciarse o continuarse con la ejecución forzada; sin embargo, la tutela se habrá otorgado cuando el juez realizó la actividad necesaria y posible para satisfacer al ejecutante, lo que sucede (más allá de haberse otorgado tutela) es que no se dan las condiciones para ejecutar la decisión.

En lo que respecta a la ejecución de un mandato judicial que impone una obligación de dar un bien cierto, podemos encontrarnos frente a estos escenarios: una imposibilidad fisica de restituir el bien por fue destruido, o una imposibilidad juridica de entregar el bien porque (por ley) salió del comercio, entre otros. Aqui nos quedará, de ser posible, solicitar una tutela sustitutoria, como actualmente se está regulando en el articulo $705^{\circ}$ del Código Procesal Civil. El problema para la ejecución (genérica, en este caso) existirá si el ejecutado no tiene patrimonio que pueda ser afectado para garantizar el pago de la compensación dineraria.

De otro lado, merece un comentario aparte aquel supuesto en donde la ejecución de las decisiones judiciales impone una prestación a cargo del Estado. Este tema resulta bastante 
controvertido, no solamente en el plano abstracto de las normas, sino en el plano concreto donde se ubican los justiciables; se atribuye responsabilidad al Ejecutivo, al Legislador y a los magistrados; lo cierto es que existe un problema real y que debe dársele la mejor solución, atendiendo a los intereses y derechos que se estén discutiendo en cada caso.

Para entender este problema con mayor facilidad, propongo el siguiente caso tramitando ante un Juzgado Especializado de la Corte Superior del Santa ${ }^{28}$. Una empresa constructora y una Municipalidad, con fecha 16 de enero de 2006, suscriben un Acta de Conciliación ante un Centro autorizado por el Ministerio de Justicia, en donde esta última reconoce a favor de la primera una deuda por $\mathrm{S} / .74,409.99$, producto de la ejecución de una obra pública: construcción de pavimento y muro de contención en una calle de la comuna; dentro del acuerdo se establece un rol de pago, desde marzo hasta diciembre de 2006 . Frente al no pago por parte de la Municipalidad, con fecha 11 de mayo de 2007, la empresa demanda la ejecución del acta de conciliación, a través de un proceso de ejecución de ejecución de resoluciones judiciales a tenor del artículo $18^{\circ}$ de la Ley 26872 (vigente a esa fecha), solicitando se ordene a la Municipalidad cumpla con pagar los S/.46,409.99, como saldo pendiente. Por resolución $\mathrm{N}^{\circ} 01$ se dicta el mandato de ejecución, ordenando a la Municipalidad cumpla con pagar dentro del plazo de 3 dias, bajo apercibimiento de iniciarse ejecución forzada. Luego que las excepciones y la contradicción formulada por la Municipalidad se declaren improcedentes; con fecha 19 de octubre de 2007, la empresa solicitó medida cautelar de embargo en forma de retención hasta S/. $60,000.00$ sobre cuentas corrientes o de ahorros que tenga la ejecutada en diversas entidades financieras y bancarias. El Juzgado declaró improcedente esta medida cautelar señalando: "en el presente caso, la demandada (...) forma parte del Sector Público, por lo tanto es de observancia las normas contenidas en la Ley número 27584 , la misma que contempla el procedimiento a seguir para hacer efectivo el cobro de la deudas", y sigue indicando: "si bien es cierto al recurrente, se le ha admitido a trámite la demanda de ejecución de acta de conciliación; también es el hecho, de que al ser amparada la demanda, la demandada tiene un tratamiento especial para que el cumplimiento de sus obligaciones, según el artículo 42 de la citada ley, resultando dicha norma de cumplimiento obligatorio por el Juez y justiciables", y finaliza precisando: "siendo como se expone, resulta prematuro proceder a la ejecución forzada cuando aún no se ha dado cumplimiento de la obligación siguiendo el procedimiento previsto en la ley". En este estado, la Sala Civil Superior confirma el auto que rechaza la contradicción, quedando firme al no interponerse recurso de casación contra ella. Posteriormente, la decisión que declara improcedente la medida cautelar fue confirmada por la Sala Superior, reiterando la misma argumentación del Juez Civil, pero precisando que para cumplir con tal obligación "se debe afectar el pliego presupuestal de la dependencia donde se generó la deuda”. Finalmente, el Juzgado dispone que el titular del pliego presupuestario considere la deuda para el ejercicio fiscal de 2008 , o presentar

Para estos efectos, se omitirá mencionar a las partes y al órgano jurisdiccional a cargo del proceso. 
cronograma de pagos, contando para tal efecto con seis meses, "bajo apercibimiento de darse inicio al proceso de ejecución de resoluciones judiciales previsto en el artículo 713 del Código Procesal Civil". Como vemos el tema es bastante complicado para el acreedor ejecutante, pues no importó que haya realizado una obra pública presupuestada, que tenga un documento que constituye cosa juzgada (acta de conciliación), que haya iniciado un proceso judicial de ejecución de resolución judicial, que obtuvo un mandato de ejecución a su favor, y que las dos instancias le dieron la razón al declarar improcedente las excepciones y la contradicción, pues al final el juzgado le dijo no puedes ejecutar tu titulo de ejecución "por ahora" (al ser, se dijo: "prematuro"), y que debe (luego de 24 meses, 10 meses de vencida la deuda, más 14 meses del transcurso del proceso) esperar 6 meses más, para ver si el Estado incorpora en el pliego presupuestario su acreencia, caso contrario, recién podría iniciar ejecución forzada contra el Estado (art. 42 de la Ley del Proceso Contencioso Administrativo) en un "nuevo proceso". ${ }^{29}$

De otro lado, no hay que dejar de observar que, al final de todo, otro problema que se le sumará al ejecutante es saber ¿cuáles son las cuentas bancarias de la Municipalidad que pueden ser afectadas con medida cautelar? Primero debemos recordar que los bienes del Estado son embargables, salvo cuando aquellos son de dominio o servicio público, justamente porque son intransferibles; a contrario sensu, solo serán embargables los bienes del Estado que son de dominio privado ${ }^{30}$. Segundo, cuando cobramos sumas de dinero al Estado, se ha previsto un procedimiento especial y previo antes de iniciarse ejecución forzada, previsto en el artículo $42^{\circ}$

29 Dando una solución al caso propuesto es oportuno citar Balcazár Quiroz, quien comentando la resolución de la Quinta Sala Civil de la Corte Superior de Lima, Exp. 5423-2005, donde se resuelve un caso similar, ha considerado (de modo interesante) que "el principio de inembargabilidad de los depósitos de dinero afectos al servicio público o al interés nacional, funciona como regla general frente a cualquier tercero, pero deviene en inaplicable frente a todos aquellos sujetos que contrataron con el Estado en función de la ejecución de un servicio público o de la ejecución de una obra de interés nacional" (Balcázar Quiroz, José. "Contratos de Ejecución de Obras Públicas y Embargos contra las Cuentas del Estado en una reciente Ejecutoria Superior. Una Interpretación conforme a la Constitución". En: Diálogo con la Jurisprudencia N ${ }^{\circ}$ 105, Año 12, Gaceta Juridica, Julio 2007, p. 40). No olvidemos, que será justamente el juez quien deberá adecuar la realidad para buscar una ejecución plena de la orden judicial, como sucedió en este caso.

30 En tal sentido, el Tribunal Constitucional en el Expediente $\mathrm{N}^{\circ} 006-96-\mathrm{I} / \mathrm{TC}$, al declarar la inconstitucionalidad de la Ley $\mathrm{N}^{\circ} 26599$ que incluyó el inciso 1 del articulo 648 del Código Procesal (sobre la inembargabilidad de los bienes del estado), estableció que solo los bienes de dominio o servicio público son los que tienen el carácter de inembargables, justamente por estar afectos a un interés público y general (Ver texto completo en: http://www.tc.gob.pe/jurisprudencia/1997/00006-1996-AI.html). Igual criterio fue asumido por el Tribunal al resolver el Expediente (acumulado) $\mathrm{N}^{\circ}$ 015-2001-Al/TC, 016-2001-AI/TC y 004-2002-AL/TC, donde se discutió la inconstitucional de las Leyes $\mathrm{N}^{\circ} 26756$ y N 27684 (Ver rexto completo en: http://www.tc.gob.pe/ jurisprudencia/2004/00015-2001-AI\%2000016-2001-Al\%200004-2002-AI.hrml). Del mismo modo, este criterio se estableció en el Pleno Jurisdiccional Civil de ano 2000, realizado en Tacna, al afirmarse que "procede el embargo de bienes de dominio privado del Estado". (Nieves-Chero, Justo. Plenos Jurisdiccionales en Materia Civil, y Acuerdos Plenarios y Sentencias Vinculantes en Materia Penal. Editorial Grijley, 2008, p. 49). 
de la Ley del Procedimiento Contencioso Administrativo ${ }^{31}$; este salvavidas que se le otorga al Estado es justamente para proteger el llamado Principio de Legalidad Presupuestaria (art. $77^{\circ}$ de la Constitución). Y, tercero, si transcurren 6 meses de la notificación judicial sin que la entidad estatal haya iniciado el pago o haya conforme al procedimiento especial (y lo debe probar), el Lstado pierde "el salvavidas" y contra él procede iniciar la ejecución forzada; se entiende exclusivamente sobre bienes de dominio privado.

Ahora, llegada la ejecución forzada el problema al querer embargar las cuentas del Estado es justamente saber cuáles son de dominio público o privado; en efecto, esta carga que se traslada al ejecutante resulta ineficaz, si preguntavámos ¿cómo el acreedor va a identificar en su solicitud cautelar las cuentas a afectar?, si ello implica pedir (previamente) información a las entidades bancarias, lo que es imposible de obtener por el llamado "secreto bancario" ${ }^{32}$. Entonces la pregunta es ¿qué hace el ejecutante?, lo más adecuado es trasladar la responsabilidad al órgano retenedor, quien deberá informar al Juzgado (dictado el embargo) si la cuenta es para fines públicos o privados; evidentemente ello implicará que el Estado lo haya declarado de modo previo ante el retenedor, exigencia que deberia estar regulada. Ahora, si la entidad estatal hace una falsa declaración le será imputable la responsabilidad administrativa y penal que corresponda. Dando una solución bastante acertada, Abad Yupanqui ${ }^{33}$ (acogiendo las propuestas de la Defensoria del Pueblo y del Tribunal Constitucional) afirma que se podria: (a) crear un registro público de deudas y de bienes del Estado, indicando cuáles son de dominio público y priva$\mathrm{do}^{34}$; (b) generar previsiones de gastos para cumplir especificamente con mandatos judiciales,

31 Hay quienes argumentan que este procedimiento especial sólo es aplicable cuando el cobro de la acreencia es exigido dentro de un proceso contencioso administrativo; sin embargo, considero que esta norma es aplicable a los demás procesos de distinta naturaleza en donde el Estado sea deudor; no olvidemos que el sistema juridico es unitario, y por tanto debe interpretarse conjuntamente; siendo asi, tendriamos que descartar la interpretación lireral en busca de proteger el indicado Principio de Legalidad Presupuestaria. Ahora bien, como lo señalan Ararma Cordero y Velàsquez Meléndez, este procedimiento especial debe ser concordado con la Ley General del Sistema Nacional de Presupuesto, Ley № 28411 (Atarama Cordero Mario y Velásquez Melèndez Raffo. "Ejecućión de sentencias que condenan al Estado al pago de sumas de dinero". En: Gaceta Constitucional, Tomo 04, Abril 2008, p. 410).

32. Según el articulo $140^{\circ}$ de la Ley $\mathrm{N}^{\circ} 26702$, Ley General del Sistema Financiero y del Sistema de Seguros y Orgánica de la Superintendencia de Banca y Seguros.

33 Abad Yupanqui, Samuel. "Ejecución de una Sentencia en los Procesos Contencioso Administrativo". En: El Derecho Administrativo y la Modernización del Estado Peruano. Ponencia del 3er. Congreso Nacional de De. recho Administrativo. Lima: Ed. Grijley, 2008, p. 35.

34. Importante es indicar que la Ley No 26756 dispuso crear una "Comisión" para que determine que bienes del Estado podian ser afectados con medidas cautelares; sin embargo, nunca se estableció relación alguna sobre tales bienes estatales; además, esta norma quedó sin efecto producto de la sentencia del Tribunal Constitucional, Expediente (acumulado) $\mathrm{N}^{\circ}$ 015-2001-Al/TC, 016-2001-Al/TC y 004-2002-Al/TC, pues se estableció el carăcter inembargable de los bienes del Estado se deriva de su propia naturaleza (bienes de dominio público o privado) y no se encuentra sujeto a la discrecionalidad del legislador (Atarama Cordero Mario y Vel.AsQuez Meléndez Raffo. Op. Cit., p. 407). 
estableciendo un porcentaje razonable del presupuesto del Estado para estas contingencias; (c) sancionar a los funcionarios que no presupuesten las deudas de su sector; y establecer responsabilidad penal, civil y administrativa si su conducta con dolo, culpa inexcusable o arbitraria; (d) Establecer legalmente que es prioritario el cumplimiento de las sentencias, asi como reconocer la posibilidad de sustituir la prestación ordenada (con indemnización, adjudicación en pago, o compensación de créditos); (e) contemplar la prelación de los pagos ordenados en sentencias judiciales; $\mathrm{y}(\mathrm{f})$ regular la posibilidad de fraccionar las prestaciones ordenadas en mandato judicial. Estas propuestas valederas deben buscar acercar el Principio de Legalidad Presupuestaria y al de Tutela Jurisdiccional Efectiva, para que Estado cumpla eficientemente con ejecutar lo ordenado en sentencia; caso contrario, de no permitirse una real ejecución forzada, y como lo ha indicado el Tribunal Constitucional, "daria lugar a que no exista una seguridad juridica ya que vano seria accionar contra el Estado, que de ser vencido no se le podria ejecutar la sentencia por existir esta protección a su favor", y destacando que "esto daria lugar para pensar o creer, con fundamento, que la persona que entable demanda al Estado no tiene derecho a una tutela jurisdiccional efectiva; y no habria una igualdad de condiciones, y se presentaría una credibilidad dudosa para el cumplimiento de las sentencias". ${ }^{35}$

\section{REFORMULANDO EL PROCESO DE EJECUCIÓN: A PROPÓSITO DEL DE. CRETO SUPREMO № 1069, DE FECHA 28.06.2008}

El Código Procesal Civil de 1993 estableció que el Proceso de Ejecución estaba compuesto por tres procesos: (i) el ejecutivo, (ii) el de ejecución de resoluciones judiciales y (iii) el de ejecución de garantias. A la fecha, producto del Decreto Supremo № 1069 se han derogado tales procesos, y se ha creado el "Proceso Único de Ejecución"; que deviene en la acumulación de los procesos anteriores; en otros términos, se ha "reordenado" el proceso moviendo algunos articulos y derogando otros. Particularmente, considero que ello no era necesario, pues las reglas (por lo general) siguen siendo las mismas; de otro lado, las precisiones que se han puesto en la nueva legislación debieron ser establecidas por la jurisprudencia, y no cambiando el Código Procesal.

A continuación, de modo breve, haremos algunos apuntes al nuevo Proceso Único de Ejecución:

- Comencemos por lo más superficial, el actual articulo $688^{\circ}$ del Código Procesal Civil establece cuales son los titulos que causan ejecución, denominándolos: "Títulos Ejecutivos"; sin embargo, a la vigencia del Código en 1993, se discutió si el llamado Proceso Ejecutivo era realmente uno de Ejecución, la mayoria de autores nacionales consideró 
que no lo era; entonces, si se buscaba crear un real proceso de ejecución (al eliminarse la audiencia, como obligatoria, y la sentencia), debió dejarse de lado el nombre de "Títulos Ejecutivos" y convertirlos (en nombre) en "Titulos de Ejecución", y no al revés.

De otro lado, este artículo solo acumula los títulos previstos en los artículos $693^{\circ}$ y $713^{\circ}$ del Código Procesal Civil; sin embargo, para mayor rigurosidad, también debió indicarse cuál es el titulo (o documentos) que generan la ejecución de una garantia real.

- El actual articulo $690^{\circ}$ del Código Procesal Civil, repite lo previsto en el texto originario; sin embargo, agrega que el constituyente de la garantia del bien a ejecutarse debe ser emplazado como litisconsorte necesario; creo que esto no era necesario, pues quedaba claro que aquél tenia necesariamente que ser parte de la relación jurídico procesal; reitero, no era indispensable modificar la norma sino establecer precedentes judiciales. Asimismo, se incluye que al tercero afectado se le deberá notificar por edictos, según el artículo $435^{\circ}$ del Código, cuando se desconoce su domicilio; como vemos, esta modificatoria resulta ser absurda, pues para ello simplemente bastaba hacer una interpretación sistemática.

- Se han incluido en el Código Procesal Civil, los artículos 609-A, 690-B, 690-C, 690-D, 690-E y 690-F. Respecto del primero no se dice nada nuevo. En relación al segundo se ha establecido una nueva regla para determinar la competencia; asi se regula que la competencia será según el titulo a ejecutar: (i) si es de naturaleza extrajudicial, serả competente el Juez de Paz Letrado, hasta una cuantia máxime 10 URP, y si excede tal monto será de competencia del Juzgado Civil; en el caso especial, que sea un titulo extrajudicial que constituya garantia sobre un bien, es competente el Juez Civil; y (ii) si es naturaleza judicial, será de competencia del Juez de la demanda.

El articulo 690-C regula el "mandato ejecutivo", al igual que pasa con el titulo ejecutivo, considero más adecuado llamarlo "mandato de ejecución". Cabe indicar que pese a la nueva nomenclatura del mandato, el nuevo artículo $690^{\circ}$ del Código Adjetivo sigue refiriéndose al "mandato de ejecución", entiendo que es solo un error material de una norma que se proyectó muy aprisa; igualmente, no se encuentra uniformidad cuando los articulos $715^{\circ}$ y $721^{\circ}$ refieren al "mandato de ejecución". Adicionalmente, respecto a la ejecución de las prestaciones no patrimoniales, tal regla ya se habia regulado en el artículo $715^{\circ}$ modificado.

Por su lado, el artículo 690-D regula la contradicción al mandato ejecutivo, haciendo una distinción (implícita, por cierto) entre la contradicción, las excepciones procesales y defensas previas, admitiéndolas en el Proceso Único de Ejecución. Respecto del derogado proceso ejecutivo era legalmente claro que si procedian las excepciones y defensas 
previas (según el originario del articulo $700^{\circ}$ del C.P.C.); sin embargo, la discusión sobre su procedencia en los procesos de ejecución (de resoluciones judiciales y de garantias) el tema estaba resuelto por el Pleno Jurisdiccional Civil de $1999^{36}$; por tanto, considero que no era una modificación indispensable. Respecto de los medios de prueba, se sigue la misma regla establecida en el modificado articulo $700^{\circ}$ del Código Procesal Civil; del mismo modo, para la ejecución de títulos de naturaleza extrajudicial se formulará contradicción (en un plazo de 5 dias) invocando la inexigibilidad o iliquidez de la obligación; la nulidad formal o la falsedad del título, o cuando el titulo valor haya sido completado en forma contraria a lo pactado, o la extinción de la obligación; aqui se repite lo regulado también en el artículo $700^{\circ}$ modificado. Lo resaltante es que cuando se ejecutan laudos firmes o actas de conciliación no homologadas, se amplia las causales de contradicción. Se hace una precisión, respecto de la contradicción a la ejecución de titulos judiciales, indicándose que procede (en un plazo de 3 dias) invocando el cumplimiento de lo ordenado, o la extinción de la obligación; y se adjuntará solo prueba instrumental (documentos) reiterando lo previsto en el articulo $718^{\circ}$ derogado.; entonces, el "proceso único" tiene reglas especiales que desvirtúan su "unidad". Algo similar sucede en las ejecuciones de garantías, pues el plazo se mantiene en 3 días, en atención al artículo $722^{\circ}$ del Código Procesal Civil, texto vigente, dejándose de lado el plazo "único" del articulo 690-D del mismo Código.

El artículo 690-E regula el trámite del Proceso Único de Ejecución. Lo destacable aqui es que se establece (por regla general) que en estos procesos no hay audiencia, pues las excepciones, las defensas previas y la contradicción se resuelven en un auto (ya no en sentencia, como sucedia en el Proceso Ejecutivo derogado); sin embargo, como excepción, se señala que "cuando la actuación de los medios probatorios lo requiera o el Juez lo estime necesario, señalará dia y hora para la realización de una audiencia”. Esta regla es un avance para los fenecidos Procesos Ejecutivos; sin embargo, un retroceso para la ejecución de una garantía, pues antes la regla era no hay audiencia, y solo se admiten documentales como prueba; ahora al admitirse como medio de prueba las declaraciones de parte (como titulo extrajudicial), se tergiversa el proceso de ejecución en tanto que el juez tendria que llamar a audiencia única para actuar esta declaración, cuando antes no era necesario; obviamente distinto seria el caso excepcional de la pericia grafotécnica, por ejemplo.

En el Pleno Jurisdiccional de 1999, llevado a cabo en el Cusco, se preguntó: ¿limita el artículo $722^{\circ}$ del Código Procesal Civil la posibilidad de proponer excepciones procesales?, y se respondió: "no se limita la posibilidad de proponer excepciones procesales. Se hacen valer dentro de la contradicción y sin dar lugar al trámite de las excepciones. Ello en virtud a que toda demanda, incluida la de ejecución de garantias, debe cumplir con los requisitos de procedencia prescritos en el articulo 427 del Código Procesal Civil, pudiéndose deducir como medio de defensa la ausencia de presupuestos procesales o de las condiciones de la acción" (NIEVEs-CHERO, Justo. Op. Cit. p. 51). 
- También se ha modificado el artículo $691^{\circ}$ del Código Procesal Civil, estableciendo un plazo único para apelar el auto que resuelven las excepciones, defensas previas y la contradicción, que ahora es de 3 dias. Se ha precisado que el plazo se cuenta desde el dia siguiente de la notificación, lo cual no era necesario señalar pues tal regla está claramente establecida en el articulo $147^{\circ}$ del mismo Código. Por lo demás, el texto es igual al que estuvo regulado en el articulo originario.

- Por su lado, el artículo 692-A reitera lo regulado en el derogado artículo $703^{\circ}$ del Código Procesal Civil, sin mayor cambio importante.

- En lo que se refiere a la ejecución de obligación de dar suma de dinero, el vigente artículo $695^{\circ}$ se remite a las normas generales, antes comentadas.

- La ejecución de una obligación de dar bien mueble determinado se regula en el articulo 704 ${ }^{\circ}$ del Código Procesal Civil, y aqui se han hecho cambios importantes, a saber: (i) se requiere que la demanda incluya el valor del bien mueble reclamado; (ii) se establece, como alternativa, en caso no se entregue el bien porque este se destruyó, deterioró, sustrajo u ocultó, que el ejecutado tendrá que pagar su valor (compensación dineraria), siempre que se haya demandado asi. En el mismo sentido, el articulo 705-A establece que determinado el valor del bien (por tasación o pericia judicial), el mismo se exige en el mismo proceso. Esta norma es un buen avance, pero considero que la conversión de la ejecución específica a la genérica debe permitirse, inclusive, en ejecución forzada, como ya se anotó; además, esta regla debió extenderse también a otros supuestos de ejecución.

- Respecto de la ejecución de obligación de hacer, los nuevos articulos 706, $708^{\circ}$ y $709^{\circ}$ no establecen reglas distintas a las anteriores; tanto así que el texto del vigente articulo $708^{\circ}$ es idéntico al modificado (¿?). Lo único reseñable es que cuando se ejecuta una obligación de formalizar un documento, el plazo para cumplir el mandato ejecutivo es de 3 días, y ya no de 5 dias; esta regla es una "especial" que escapa del plazo general previsto en el articulo 690-D.

- La regulación de la ejecución de obligaciones de "no hacer" ha tenido una inserción importante. El actual artículo $712^{\circ}$ del Código Procesal indica que cuando se exija "deshaga" lo hecho, aquello puede ser ejecutado por un tercero, asumiendo el ejecutado el costo que se genere, y el pago será exigido en el mismo proceso. Lo que si debe entenderse es que en los demás casos cuando se trata de un "no hacer" existe una obligación personalisima que no puede ser trasladada a terceros, supuesto en donde este precepto legal no resulta aplicable. 
- El actual artículo $715^{\circ}$ del Código Procesal Civil, señala que si se exige una prestación sin contenido patrimonial, el Juez deberá adecuar el apercibimiento en cada caso; esta regla, se remite del texto original. Sin embargo, se establecen nuevas reglas procedimentales: (i) si el proceso ya cuenta con una medida cautelar, este cuaderno se agregará al principal, y se refoliará, para que todo obre en una sola cuerda; esto no hace más que referirse (indirectamente, claro está) a la llamada "conversión de una medida cautelar a una medida ejecutiva”, regulada en el Código Procesal Constitucional; y (ii) si el proceso no cuenta con medida cautelar ejecutada, en este estado podrá solicitarse una medida de ejecución (o ejecutiva). Por otro lado, el vigente artículo $716^{\circ}$ del Código Procesal, en la misma linea, señala que frente a la ejecución de sumas liquidas procederá, a pedido de parte, medidas de ejecución siguiendo las reglas de las medidas cautelares para futura ejecución forzada. Así vemos, en estricto, no era indispensable esta última modificatoria, pues más allá de la denominación asi se vienen ejecutando en la actualidad.

- Dentro del Proceso Único de Ejecución encontramos a la ejecución de garantías, regulado en el artículo $720^{\circ}$ del Código Procesal Civil. El texto vigente no tiene mayor variación en relación al texto originario, salvo cuando se impone la obligación de notificar al deudor, al garante y al poseedor del bien, cuando son personas distintas. Nuevamente, esta precisión es innecesaria en tanto que para ello ya existía el artículo $690^{\circ}$ del Código Adjetivo.

Por su lado, se ha modificado el artículo $724^{\circ}$ del Código Procesal indicándose que el saldo de la deuda no pagada, luego del remate, se puede exigir en el mismo proceso, y ya no en un "nuevo proceso ejecutivo" como parecia indicar el texto originario de la norma. La regla actual resulta más clara, pues concuerda de mejor manera con el artículo $692^{\circ}$ del Código Procesal Civil, que en una interpretación a contrario sensu reconoce la posibilidad de embargar bienes del deudor, en el mismo proceso, cuando la garantía real sea insuficiente.

- El capitulo de ejecución forzada no ha sufrido mayores cambios, en tanto que solo se han modificado las siguientes normas: (i) el articulo $732^{\circ}$, en donde se establece que el Juez puede regular los honorarios del martillero, atendiendo a su participación o intervención en el remate e incidencias en la ejecución; (ii) el artículo $733^{\circ}$, a través del cual se precisa que el juez puede notificar, via correo electrónico, a diario encargado de los avisos judiciales para que proceda a publicar el aviso de remate, se precisa que este extremo de la norma está suspendido por 180 días, según la Segunda Disposición Complementarias y Transitorias del Decreto Legislativo No 1069. De otro lado, se ha omitido (entiendo involuntariamente) regular el pegado de avisos cuando se rematan bienes muebles, sin embargo, considero que deberá aplicarse supletoriamente lo previsto para los 
bienes inmuebles; $y$ (iii) el articulo $739^{\circ}$ inciso 2, agrega que el auto de transferencia del inmueble ejecutado debe disponer (además) la cancelación de "las cargas o derechos de uso $\mathrm{y} / \mathrm{o}$ disfrute, que se hayan inscrito con posterioridad al embargo o hipoteca materia de ejecución"; esto entiendo debe querer indicar que "las cargas o derechos inscritos con anterioridad seguirán vigentes y mantendrán su vigencia", siendo asi, no era imprescindible hacer esta precisión pues a la misma conclusión llegamos si aplicamos los principios registrales vigentes.

Luego de lo antes expuesto, considero que la modificación incluida por el Decreto Legislativo 1069 no era indispensable, ni urgente; excepto en aquellos dos supuestos ya mencionados. Además, creo que si se trataba de mejorar el proceso (o etapa) de ejecución se debieron tratar otros temas más importantes; por ejemplo: (i) reconocer expresamente las facultades coercitivas del juez para ejecutar sus decisiones, (ii) establecen un sistema de apremios efectivos, incluyendo a las multas, astreintes, prisión civil, subrogación por tercero, destitución del obligado, y conversión a la ejecución genérica, en casi todos los supuestos; (iii) regular los medios para ejecutar forzadamente las obligaciones de dar, hacer y no hacer, patrimoniales o extrapatrimoniales, personalisimas o no; y (iv) modificar el concepto legal de ejecución forzada, extendiéndolo a todo tipo de mandato de condena, y no sólo para aquellos que implican una obligación de dar suma de dinero.

\section{A MODO DE CONCLUSIÓN}

La tutela jurisdiccional tiene que ser efectiva para que se le otorgue al justiciable un derecho real y concreto; siendo asi, si la decisión judicial no se ejecuta o no se materializa en la realidad no se podrá hablar de una tutela efectiva. De ahi que se deben otorgar a los litigantes todos los mecanismos para que puedan lograr una ejecución total de decisión judicial y, por ende, lograr una satisfacción procesal plena; caso contrario, no sería económicamente ineficiente seguir todo un proceso judicial para al final no poder materializar aquel derecho reconocido judicialmente, se invertiria dinero, tiempo y esfuerzo innecesariamente; además, ello es expresión justamente del poder-deber que ostentan los jueces, quien no solo deben juzgar sino también ejecutar lo juzgado.

Finalmente, la inoperatividad de la ejecución de las decisiones judiciales no solo afecta al sistema judicial, sino también al estado de derecho; pues no podria hablarse de este ủltimo si precisamente no se dan las garantias suficientes para generar seguridad juridica a los justiciables; más aún, si en ocasiones es el Estado quien incumple los mandatos judiciales, agraviando el derecho de igualdad. 


\section{BIBLIOGRAFÍA CONSULTADA}

ABAD YUPANQUI, Samuel y otros. Código Procesal Constitucional. Comentarios, Exposición de Motivos, Dictämenes e Indice Analitico. Lima: Palestra Editores, 2004.

ARIANO DEHO, Eugenia. Problemas del Proceso Civil, Lima: Juristas Editores, 2003.

CALAMANDREI, Piero. Introducción al Estudio Sistemático de las Providencias Cautelares, Buenos Aires: Lib. El Foro, 1996.

CARRIÓN LUGO, Jorge. Procesos de Ejecución. Titulos Ejecutivos y de Ejecución, Lima: Ed. Grijley, 2008.

CHIARLONI, Sergio. "Medidas Coercitivas y Tutela de los Derechos", Lima: Palestra Ed., 2005.

COUTURE, Eduardo J. Fundamentos del Derecho Procesal Civil, Buenos Aires: Edit. De Palma, Buenos Aires, 1988.

GIMENO SENDRA, Vicente. Derecho Procesal Civil. I. Parte General, 3ra. Edición. Madrid: Colex Ed., 2005.

HURTADO REYES, Martin. "Tutela Jurisdiccional Diferenciada", Lima: Palestra Editores, 2006.

MARINONI, Luiz. Derecho Fundamental a la Tutela Jurisdiccional Efectiva, Lima: Palestra Ed., 2007.

MARTEL CHANG, Rolando. Tutela Cautela y Medidas Autosatisfactivas en el Proceso Civil, Lima: Palestra Ed., 2003.

MONROY GALVEZ, Juan. Introducción al Proceso Civil, Tomo I. Santa Fé de Bogotá: Ed. Temis, 1996.

MONROY PALACIOS, Juan José. Bases para la Formación de una Teoria Cautelar, Lima: Ed. Comunidad 2002.

MONROY PALACIOS, Juan José. La Tutela Procesal de los Derechos, Lima: Palestra Ed., 2004.

MONTERO AROCA, Juan y otros. El Nuevo Proceso Civil, Valencia: Tirant Lo Blanch, 2000.

MONTEO AROCA, Juan y otros. Derecho Jurisdiccional. Proceso Civil Tomo II, 12a. Edición, Valencia: Tirant Lo Blanch, 2003. 
NIEVES-CHERO, Justo. Plenos Jurisdiccionales en Materia Civil, y Acuerdos Plenarios y Sentencias Vinculantes en Materia Penal, Lima: Editorial Grijley, 2008.

OBANDO BLANCO, Victor Roberto. El Derecho a la Tutela Jurisdiccional Efectiva en la Jurisprudencia, Lima: Palestra Ed., 2001.

RUBIO CORREA, Marcial. La Interpretación de la Constitución según el Tribunal Constitucional, Lima: Fondo Editorial PUCP, 2005.

TORRES VÁSQUEZ, Anibal. Diccionario de Jurisprudencia Civil, Lima: Ed.Grijley, 2008.

ZELA VILLEGAS, Aldo. La Tutela Preventiva de los Derechos (como manifestación de la tutela diferenciada), Lima: Palestra Ed., 2008.

\section{REVISTAS Y OTROS}

Congreso Internacional de Derecho Procesal Civil, Lima: Fondo de Desarrollo Editorial de la Universidad de Lima, 2003.

Diälogo con la Jurisprudencia N 105, Año 12, Gaceta Juridica, Julio 2007.

"El Derecho Administrativo y la Modernización del Estado Peruano". Ponencia del 3er. Congreso Nacional de Derecho Administrativo, Lima: Ed. Grijley, 2008.

Gaceta Constitucional, Tomo 04, Abril 2008.

La Revista Virtual Hechos de la Justicia, N 01, Noviembre-Diciembre 2003.

La Revista Virtual Hechos de la Justicia, № 05, Enero-Marzo 2005.

Revista Peruana de Derecho Procesal, Tomo VI, Estudio Monroy Abogados, Mayo 2003.

Revista Peruana de Derecho Procesal, Tomo VIII, Estudio Monroy Abogados, Septiembre 2005.

Revista El Derecho: Orientaciones y Tendencias sobre el Código Procesal Civil, № 298, Colegio de Abogados de Arequipa, Diciembre 1993.

Suplemento de Análisis Legal "Juridica” del Diario Oficial El Peruano, 8 de noviembre de 2005, Año $\mathrm{N}^{\circ} 02, \mathrm{~N}^{\circ} 71$. 
